\title{
Particulate matter fluxes in the southern and central Kara Sea compared to sediments: Bulk fluxes, amino acids, stable carbon and nitrogen isotopes, sterols and fatty acids
}

\author{
Birgit Gaye $^{\mathrm{a}, *}$, Kirsten Fahl ${ }^{\mathrm{b}}$, Lyudmila A. Kodina ${ }^{\mathrm{c}}$, Niko Lahajnar ${ }^{\mathrm{a}}$, Birgit Nagel ${ }^{\mathrm{a}}$, \\ Daniela Unger ${ }^{\mathrm{d}}$, A. Catalina Gebhardt ${ }^{\mathrm{b}}$ \\ anstitut für Biogeochemie und Meereschemie, Universität Hamburg, Bundesstraße 55, D-20146 Hamburg, Germany \\ ${ }^{\mathrm{b}}$ Alfred Wegener Institut für Polar- und Meeresforschung, Columbusstraße, 27515 Bremerhaven, Germany \\ ${ }^{\mathrm{c}}$ Vernadsky Institute of Geochemistry and Analytical Chemistry, Russian Academy of Sciences, 19 Kosygin Street, Moscow 11975, Russia \\ ${ }^{\mathrm{d}}$ Zentrum für Marine Tropenökologie, Fahrenheitstraße 6, D-28359 Bremen, Germany
}

Received 17 August 2006; received in revised form 11 July 2007; accepted 19 July 2007

Available online 2 August 2007

\begin{abstract}
The Kara Sea is one of the arctic marginal seas strongly influenced by fresh water and river suspension. The highly seasonal discharge by the two major rivers Yenisei and $\mathrm{Ob}$ induces seasonal changes in hydrography, sea surface temperature, ice cover, primary production and sedimentation. In order to obtain a seasonal pattern of sedimentation in the Kara Sea, sediment traps were deployed near the river mouth of the Yenisei (Yen) as well as in the central Kara Sea (Kara) within the framework of the German-Russian project "Siberian River run-off; SIRRO". Two and a half years of time-series flux data were obtained between September 2000 and April 2003 and were analyzed for bulk components, amino acids, stable carbon and nitrogen isotopes as well as sterols and fatty acids.

Sediment trap data show that much of the annual deposition occurred under ice cover, possibly enhanced by zooplanktonic activity and sediment resuspension. An early bloom of ice-associated algae in April/May occurred in the polynya area and may have been very important to sustain the life cycles of higher organisms after the light limitation of the winter months due to no/low insolation and ice cover. The strong river input dominated the months June-August in the southern part of the Kara Sea. The central Kara Sea had a much shorter productive period starting in August and was less affected by the river plumes. Despite different time-scales of sampling and trapping biases, total annual fluxes from traps were in the same order of magnitude as accumulation rates in surface sediments. Terrestrial organic carbon accumulation decreased from 10.7 to $0.3 \mathrm{~g} \mathrm{C} \mathrm{m}^{-2} \mathrm{a}^{-1}$ from the riverine source to the central Kara Sea. Parallel to this, preservation of marine organic matter decreased from $10 \%$ to $2 \%$ of primary productivity which was probably related to decreasing rates of sedimentation.
\end{abstract}

(C) 2007 Elsevier Ltd. All rights reserved.

Keywords: Seasonality; Sediment traps; River discharge; Carbon and nitrogen isotopes; Amino acids; Sterols; Fatty acids; Arctic; Kara Sea; Ob; Yenisei

\footnotetext{
*Corresponding author. Tel.: + 4940428387088 ; fax: + 4940428386347 .

E-mail address: birgit.gaye@zmaw.de (B. Gaye).
} 


\section{Introduction}

About $10 \%$ of the global freshwater discharge occurs in the Arctic Ocean (Aagaard, 1994). More than one-third of it is discharged into the Kara Sea (Fig. 1), mainly via the Yenisei and $\mathrm{Ob}$, the second and third largest arctic rivers transporting annually about $1000 \mathrm{~km}^{-3}$ water (Milliman and Meade, 1983; Telang et al., 1991). The associated supply of more than $22 \times 10^{6} \mathrm{ta}^{-1}$ of sediment, estimated at the northernmost gauging stations is small compared to rivers of similar size from lower latitudes (Milliman and Meade, 1983). Low total suspended matter (TSM) concentrations in addition to low concentrations of the dissolved fraction are due to arctic climate and the related limited vegetation and land use in the catchment (Holmes et al., 2002). Change in land use and global warming have recently increased nutrient concentrations and water discharge in arctic rivers (Peterson et al., 2002). Partial

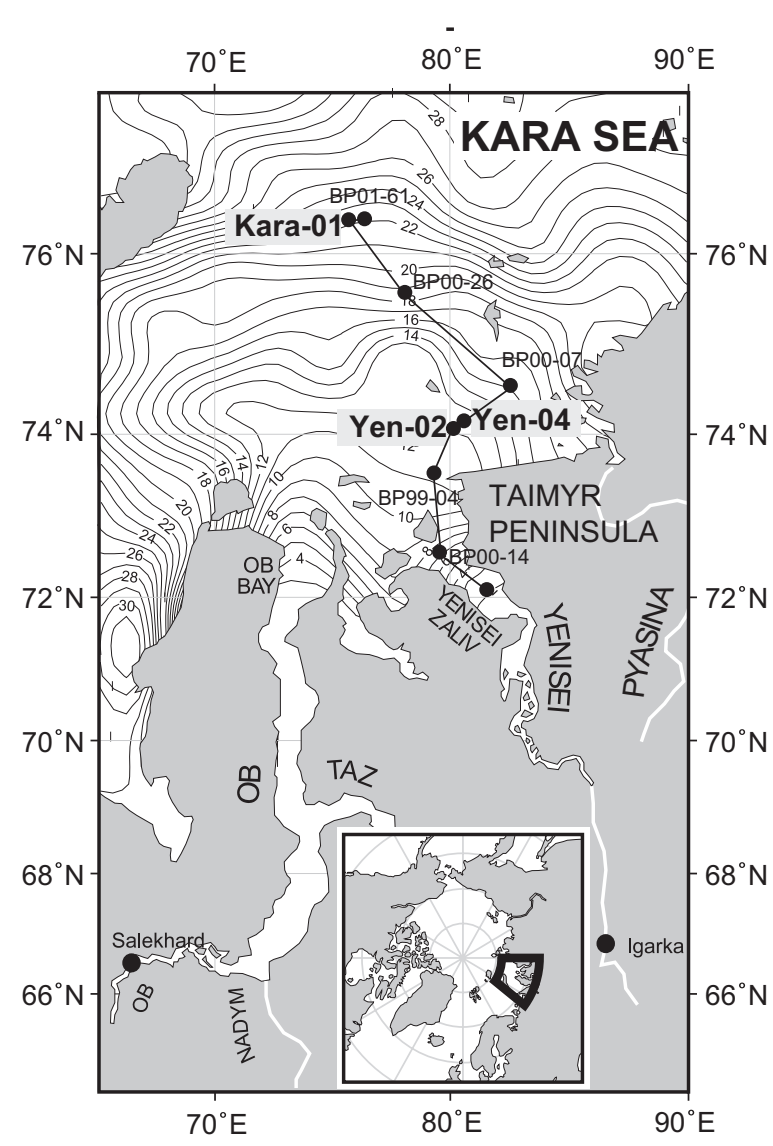

Fig. 1. Map of trap locations in the Kara Sea and isohalines (in psu) of compiled summer salinities (Dmitrenko et al., 1999). Kara-01: Kara Sea 01; Yen-2, Yen-04: Yenisei 02 and 04. melting of the permafrost soils may further increase nutrient and suspended matter concentrations in the near future (Syvitski, 2002) leading to enhanced productivity in the arctic coastal seas also stimulated by longer ice-free periods.

It was one of the aims of the multidisciplinary Russian-German research project "Siberian River run-off (SIRRO)" to understand the role of river supply for the recent sedimentation processes in the Kara Sea (Stein et al., 2003). Sediment traps were deployed in order to obtain information about processes taking place during the winter and spring season when ice cover or ice melt make the area difficult to access. The data presented here are the first seasonal particle flux data of high resolution from the southern and central Kara Sea and provide three records of seasonal changes in vertical fluxes to its deep saline water layer.

\section{Materials and methods}

\subsection{Study area}

Hydrography of the Kara Sea has a climatically induced high seasonality. The southern Kara Sea is ice free only from mid-July to mid-October (Pavlov and Pfirman, 1995) (www.aari.nw.ru). The central and northern Kara Sea remain ice covered until the end of August in most years. Maximum river discharge occurs in June (Fig. 2a), both, on and under the ice with the peak being more pronounced in the Yenisei than in the Ob (Meade et al., 2000). The high discharge period is characterised by strong stratification with warmer and less saline surface water and a deep salt wedge intruding into the estuaries (Harms et al., 2003). The thermohalocline separating surface and deep water masses is situated at about 6-8 $\mathrm{m}$ in the inner Kara Sea and can be at $20 \mathrm{~m}$ water depth in the offshore areas (Pavlov and Pfirman, 1995; Shmelkov et al., 2002). In summer the average salinity is around 10 in the surface waters of the estuaries and increases to $>30$ in the northern Kara Sea (Fig. 1) whereas in winter the river plume water mass is restricted to a narrow belt along the coast line (Pivovarov et al., 2003).

Long-term records of freshwater and suspended matter discharges are available from several hydrographic stations along both rivers (Bobrovitskaya et al., 1997; Meade et al., 2000; Holmes et al., 2001). TSM supply to the Kara Sea after dam constructions in the upper reaches of the rivers was estimated as $4.2 \times 10^{6} \mathrm{ta}^{-1}$ at Igarka for the Yenisei 

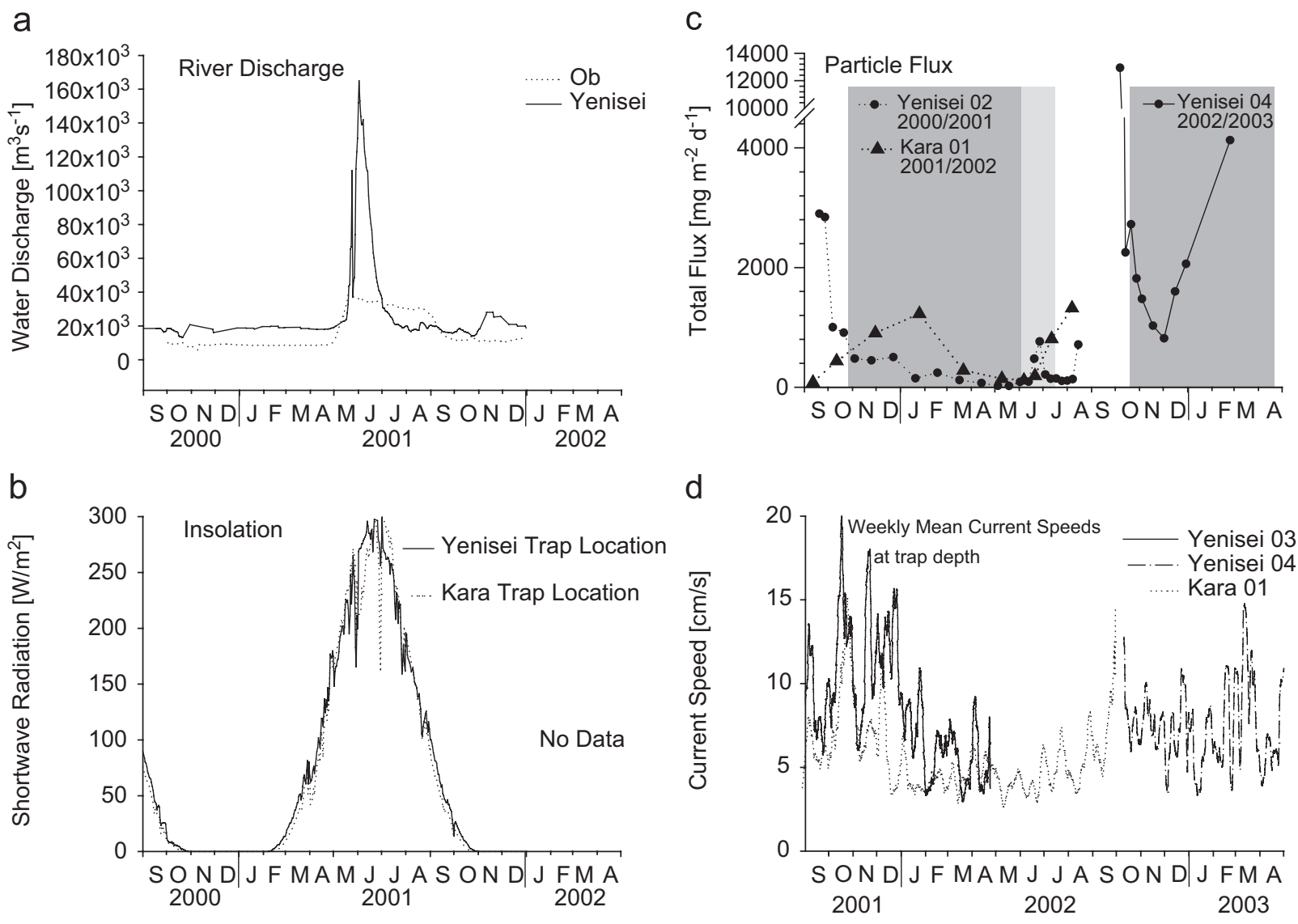

Fig. 2. Water discharge by the $\mathrm{Ob}$ at Salekhard and by the Yenisei at Igarka (a) insolation at the Yenisei and Kara trap locations (b) total particle fluxes measured by sediment traps (c) weekly averages of current speeds in $\mathrm{cm} / \mathrm{s}$ measured by current meters deployed at $55 \mathrm{~m}$ at the Kara Sea and at 21 and $30 \mathrm{~m}$, respectively, at the Yenisei location (d). Note the different dates on the $x$-axis.

and $16.2 \times 10^{6} \mathrm{ta}^{-1}$ at Salekhard for the $\mathrm{Ob}$ (Bobrovitskaya et al., 1996). Both northernmost gauging stations are about $600 \mathrm{~km}$ south of the rivers mouths (Fig. 1). A recent calculation of TSM and particulate organic carbon (POC) fluxes at the river mouths suggests a TSM discharge by the Yenisei $\left(5 \times 10^{6} \mathrm{tsediment}^{-1}\right)$ comparable to the above earlier estimate from Igarka indicating that the lower Yenisei is mainly a by-pass system (Gebhardt et al., 2004). The Ob discharge reaching the Kara Sea $\left(3.76 \times 10^{6} \mathrm{ta}^{-1}\right)$ appears to be only about one-fourth of the amount discharged at Salekhard, which may be due to deposition in the Ob Bay (Gebhardt et al., 2004). Flood events occurring about every 10 years (Bobrovitskaya et al., 1996) may, however, periodically transport this material to the Kara Sea (Gebhardt et al., 2004). Most of the TSM and organic matter reaching the Kara Sea is deposited as a thick sediment package extending from the estuaries to about $74^{\circ} \mathrm{N}$ (Dittmers et al., 2003). This region was named the "marginal filter" as flocculation and deposition may remove most of the river contaminants from the water column and thus prevent their export to the central Arctic Ocean (Lisitzyn, 1995). Several studies based on stable isotopes and biomarkers showed that most organic matter preserved in the sediments of the southern Kara Sea was of terrestrial origin (Fahl et al., 2003; Fernandes and Sicre, 1999; Krishnamurthy et al., 2001). These findings are similar to those on other Arctic shelves such as the Beaufort Sea (Goni et al., 2005).

Enhanced primary productivity is mainly restricted to the short ice-free period in late summer or may take place in the polynya area (Wassmann et al., 2004) which is situated in the southern Kara Sea north of the fast ice zone (Harms et al., 2000). Primary productivity can attain rates of more than $200 \mathrm{mg} \mathrm{C} \mathrm{m}^{-2} \mathrm{~d}^{-1}$ north of the areas of high 
turbidity from river suspension (Vedernikov et al., 1995; Vinogradov et al., 2000). Timing of ice break up and ice drift varies interannually and is largely controlled by winds that together with seasonal river discharge make the whole Arctic a region of very patchy and variable primary production and POC export during the season of sufficient light and ice-free conditions (Wassmann et al., 2004). Vinogradov et al. (2000) estimated a total primary production of $20 \times 10^{6} \mathrm{tCa}^{-1}$ for the entire Kara Sea. Nöthig et al. (2003) and Deubel et al. (2003) found large interannual differences not only in total biomass but also in spatial distribution and composition of phyto- and zooplanktonic communities in the Kara Sea-evidently driven by the timing and amount of river run-off. Short-term trap deployments showed that plankton blooms with very high fluxes of fresh organic matter can occur off the river mouths in late summer when river discharge is reduced (Gaye-Haake et al., 2003; Hirche et al., 2006).

The processes described above result in a complex structure and variable distribution of water masses in the Kara Sea characterised by different temperatures, nutrient and oxygen concentrations (Pivovarov et al., 2003). Sedimentation processes in the Kara Sea can, therefore be expected to be very complex and variable depending on river discharge, ice conditions, water mass distribution and circulation.

\subsection{Sampling}

Samples were obtained at a southern (Yen) and northern (Kara) location (Fig. 1) using two cylindrical sediment traps (Hydrobios, Kiel, Germany, http://www.hydrobios.de) equipped with, respectively 24 and 12 collection cups. The height of the collecting cylinder is $90 \mathrm{~cm}$, the diameter of its opening area is $14 \mathrm{~cm}$. Sampling intervals varied from 6.5 to 56 days according to the expected variations in particle fluxes in order to collect material sufficient for analyzes. The Yen 02 trap was deployed from September 2000 to August 2001 at a depth of $20 \mathrm{~m}$ at $74^{\circ} 00.28^{\prime} \mathrm{N}, 80^{\circ} 00.45^{\prime} \mathrm{E}$; total water depth was $31 \mathrm{~m}$. The Kara 01 trap was deployed from September 2001 to August 2002 at $76^{\circ} 12.08^{\prime} \mathrm{N}, 75^{\circ} 45.3^{\prime} \mathrm{E}$ at a water depth of $54 \mathrm{~m}$. Total water depth was $73 \mathrm{~m}$ at this location. A second trap system moored at the Yen site (Yen 03) did not collect samples due to water inflow into the electronic housing. The Yen 04 deployment $\left(74^{\circ} 00.1145^{\prime} \mathrm{N} ; 80^{\circ} 19.4613^{\prime} \mathrm{E}\right)$ had a trap depth of
$29 \mathrm{~m}$ and a total water depth of $40 \mathrm{~m}$ and collected 10 samples from October 2002 to April 2003 until water flowed into the electronic housing and stopped further sampling. Aanderaa current meters RCM 9 were deployed at trap depths from September 2001 to April 2002 at the Yen and Kara stations (Yen 03, Kara 01) and from October 2002 to April 2003 at the Yen station (Yen 04).

After recovery trap samples were immediately cooled at $4{ }^{\circ} \mathrm{C}$ until further processing. Before splitting into aliquots by a rotary splitter, swimmers were picked out. Aliquots for geochemical analyses were filtered on preweighed polycarbonate filters $(0.45 \mu \mathrm{m})$ and dried at $40^{\circ} \mathrm{C}$. For analyses samples were removed from the filters and ground in an agate mortar. Yen 02 samples number $7-18$ were filtered on GFF filters of which small portions were cut out and used for analyses. Biogenic Opal could not be determined on these samples

\subsection{Methodological limitations of sediment trap experiments}

Trapping efficiencies depend on sediment trap geometry, current speeds, particle size and tilt of traps (Gardner, 1999; Gust et al., 1992; Gust and Kozerski, 2000). Generally, cylindrical traps seem to collect more material with increasing current speeds (Gust et al., 1996). Flux amounts are also affected by active swimmers which die from the trap poison and add to the material caught in traps (Lee et al., 1988, 2000). Furthermore, the solubilization of collected particles in sampling cups strongly affects shallow traps (Antia, 2005). Solubilization within the first few days of storage in the sampling cups may reduce carbon as well as other biogenic element fluxes considerably (Kähler and Bauerfeind, 2001). This may not only change the quantity but also the quality of fluxes (Antia, 2005). Kähler and Bauerfeind (2001) did, however, not find an effect on the seasonality of fluxes and composition as recorded in traps suggesting that the solubilization takes place immediately and is insignificant after the first few days. Except for a careful picking of swimmers from trap samples we did not correct for these biases but evaluate them in the discussion.

\subsection{Analytical procedures}

\subsubsection{Bulk components}

Total carbon and nitrogen were measured by a flash combustion CNS Carlo Erba 1500 analyzer 
(Erba Science, Milan, Italy). The precision of this method is $0.15 \%$ for carbon and $0.005 \%$ for nitrogen. $\mathrm{C} / \mathrm{N}$-ratios were calculated on a molar basis. Carbonate percentages were determined by a Wösthoff Carmhograph 6 (Bochum, Germany) of all suspended matter samples from 1999, all sediment samples from 1997 and all trap samples as well as selected sediment and suspended matters samples from the subsequent sampling campaigns. The standard deviation of results is $1 \%$. All carbonate measurements were below $0.2 \%$. As this is very close to the detection limit we further assumed that total carbon equals organic carbon. Biogenic opal was determined photometrically in a modified version of the method of Mortlock and Froehlich (1989). All bulk components are presented as weight $\%$.

\subsubsection{Amino acids (AA) and hexosamines}

Total hydrolysable AA were analyzed with a Pharmacia LKB Alpha Plus 4151 AA Analyzer (Freiburg, Germany). After hydrolysis of $30-40 \mathrm{mg}$ for sediments and 2-4 mg for sediment trap material with $6 \mathrm{~N} \mathrm{HCl}$ for $22 \mathrm{~h}$ at $110^{\circ} \mathrm{C}$ an aliquot of the hydrolyzed sample was evaporated to dryness in a rotary evaporator. To remove acid the sample was taken up in deionised water three times and evaporated to dryness. The sample was then taken up in a citrate buffer of which $50 \mu 1$ were injected into the Amino Acid Analyzer. Separation was carried out by a cation exchange resin (type $475-6 \mu \mathrm{m})$ from which the momomers were eluted with citrate buffers of different concentrations, $\mathrm{pH}$ and at different temperatures. After elution a reagent containing phthaldialdehyde was added which reacted with amino acids forming a fluorescent complex. Fluorescence intensity was measured with a Shimadzu FLD-6A fluorescence detector (excitation wavelength: $350 \mathrm{~nm}$; fluorescent wavelength: $450 \mathrm{~nm}$ ). AA concentrations were quantified by comparison with an AA standard (SIGMA AA-S-18) which was run after every eighth sample. Duplicate analysis resulted in a relative error of $4 \%$ for total AA.

In addition to the total concentrations specific AA ratios were used as indicators of organic matter degradation intensity. The ratio of the aromatic AA tyrosine and phenylalanine to the non-protein amino acids $\beta$-alanine and $\gamma$-aminobutyric acid (RI; Jennerjahn and Ittekkot, 1999) is higher when organic matter is fresher as the aromatic AA are among the most labile whereas the latter are the most stable AA. Similarly, the ratio of aspartic acid to $\beta$-alanine was often used to determine the relative state of degradation as the latter is probably the degradation product of aspartic acid or may not be taken up by organisms as it is not among the essential AA (Ittekkot et al., 1984; Lee, 1988; Lee and Cronin, 1982, 1984).

The molar percentages of the 14 protein AA were used to calculate the degradation index (DI) developed by Dauwe and Middelburg (1998) and Dauwe et al. (1999) which assesses the diagenetic alteration of a sample by comparing it to a set of 28 samples of different degradation states and environments. Molar percentages of individual AA are standardised by the mean and standard deviations of the 28-sample data set. The DI then integrates the AA weighed by the factor coefficients for the first axis of the principal component analyses (PCA) of Dauwe et al. (1999) according to the formula:

$\mathrm{DI}=\sum_{i}\left[\frac{\operatorname{var}_{i}-\mathrm{AVGvar}_{i}}{\operatorname{STDvar}_{i}}\right]$ fac.coef $_{\cdot i}$

where $\operatorname{var}_{i}$ is the original mole percentage of each $\mathrm{AA}_{i}, \mathrm{AVGvar}_{i}$ and $\mathrm{STDvar}_{i}$ are the mean and standard deviations and fac.coef. ${ }_{i}$ is the factor coefficient of the first axis of the PCA of Dauwe et al. (1999). The DI thus represents the cumulative deviation with respect to an assumed average molar composition with negative values indicating more and positive values less degradation than the average.

The DI of Dauwe et al. (1999) is based on a set of marine samples whereas our samples include soil, freshwater and brackish samples. We, therefore, carried out a factor analysis on our set of samples using the program SPSS 15.0. Prior to performing the factor analysis on $\mathrm{mol} \%$ of amino acids and other variables they were standardised by subtracting the mean of all values from individual results and dividing by the standard deviation of all measurements.

\subsubsection{Stable isotopes}

$\delta^{15} \mathrm{~N}$ and $\delta^{13} \mathrm{C}$ values were determined using a Finnigan MAT 252 mass spectrometer after hightemperature flash combustion in a Carlo Erba NA-2500 elemental analyzer at $1100^{\circ} \mathrm{C}$. Pure tank $\mathrm{N}_{2}$ calibrated against the reference standards International Atomic Energy Agency IAEA-N-1 and IAEA-N-2 was used as a working standard. $\delta^{15} \mathrm{~N}$ is given as the per mil deviation from the $\mathrm{N}$-isotope 
composition of atmospheric $\mathrm{N}_{2}$. Analytical precision was better than $0.1 \%$ based on replicate measurements of a reference standard. Duplicate measurements of samples resulted in a mean deviation of $0.2 \%$. $\delta^{13} \mathrm{C}$ was measured after the removal of carbonate by $2 \mathrm{~N} \mathrm{H}_{3} \mathrm{PO}_{4}$ and is given as the per mil deviation from the isotopic composition of the PDB standard.

\subsubsection{Sterols and fatty acids}

Sterols and fatty acids were determined in the Yen 02 and Kara 01 samples. For lipid analyses the samples were extracted three times with dichloromethane/methanol (2:1, by volume). The total extract was transesterified using $3 \mathrm{~N}$ methanolic $\mathrm{HCl}\left(50^{\circ} \mathrm{C}\right.$ for $\left.12 \mathrm{~h}\right)$, a method modified according to Christie (1990) and Conte et al. (1992), and separated into fractions by column chromatography after eluting with $5 \mathrm{ml}$ hexane for the hydrocarbons, $4 \mathrm{ml}$ dichloromethane for the fatty acids and $5 \mathrm{ml}$ ethylacetate:hexane (20:80, by vol.) for the sterols. The sterols were silylated with $500 \mu \mathrm{l}$ bis-trimethylsilyltrifluoroacetamide (BSTFA) $\left(60{ }^{\circ} \mathrm{C}\right.$ for $\left.2 \mathrm{~h}\right)$. All compounds were analyzed with a Hewlett Packard gas chromatograph (HP 6890, column $30 \mathrm{~m} \times$ $0.25 \mathrm{~mm}$; film thickness $0.25 \mu \mathrm{m}$; liquid phase: DB5MS) using a temperature program as follows: $60{ }^{\circ} \mathrm{C}(2 \mathrm{~min}), 150^{\circ} \mathrm{C}$ (rate: $15^{\circ} \mathrm{C} / \mathrm{min}$ ), $320{ }^{\circ} \mathrm{C}$ (rate: $3{ }^{\circ} \mathrm{C} / \mathrm{min} ; 20 \mathrm{~min}$ isothermal). The injection volume was $1 \mu 1$ using a cold injection system (temperature program: $60^{\circ} \mathrm{C}(0.1 \mathrm{~min}), 320^{\circ} \mathrm{C}$ (rate: $12^{\circ} \mathrm{C} / \mathrm{s}$, $60 \mathrm{~s})$ ). Helium was used as carrier gas $(1.5 \mathrm{ml} / \mathrm{min})$.

The identification of the sterols and fatty acids was supported by GC/MS, which consisted of a gas chromatograph (HP 5890, column $30 \mathrm{~m} \times 0.25 \mathrm{~mm}$; film thickness $0.25 \mu \mathrm{m}$; liquid phase: DB-5MS) and a mass spectrometer (MSD, HP 5972, $70 \mathrm{eV}$ electron-impact ionisation, Scan $50-650 \mathrm{~m} / \mathrm{z}$, $1 \mathrm{scan} / \mathrm{s}$, ion source temperature $175^{\circ} \mathrm{C}$ ). GC analysis was performed with the following temperature program: $60^{\circ} \mathrm{C}(2 \mathrm{~min}), 150^{\circ} \mathrm{C}$ (rate: $15^{\circ} \mathrm{C} / \mathrm{min}$ ), $320^{\circ} \mathrm{C}$ (rate: $3{ }^{\circ} \mathrm{C} / \mathrm{min} ; 20 \mathrm{~min}$ isothermal). The injection volume was $1 \mu \mathrm{l}$ (splitless). Helium was used as carrier gas $\left(1.2 \mathrm{ml} / \mathrm{min}\right.$ at $\left.60{ }^{\circ} \mathrm{C}\right)$. The identification of the sterols and fatty acids was carried out on the basis of GC retention time and MS fragmentation pattern. For quantification 19:0 fatty acid methyl ester and cholest-5-en-3 $\beta$-ol-2, $2,3,4,4,6-\mathrm{d}_{6}$ were added as internal standards before any extraction and analytical step.

For the interpretation of the sediment trap data we use four sterols, 24-methylcholesta-5,22-E-dien-
$3 \beta$-ol (brassicasterol), $4 \alpha, 23,24$-trimethyl- $5 \alpha$-cholest$22 \mathrm{E}$-en-3 $\beta$-ol (dinosterol), 24-ethylcholest-5-en-3 $\beta$ ol $(\beta$-sitosterol) and 24-methylcholest-5-en- $\beta$-ol (campesterol), and four fatty acids, cis-11eicosenoic acid (20:1(n-9)), cis-13-eicosenoic acid (20:1(n-7)), and the two isomeres of cis-docosenoic acid (22:1 (n-11), 22:1(n-9)). All data are available on http:// www.pangaea.de.

\section{Results}

\subsection{Current speeds and directions}

In the deep layer of saline water current speeds (daily averages to remove tidal signal) reached maxima of $35 \mathrm{~cm} / \mathrm{s}$ in $2001 / 2002$ and were slightly lower at the Kara than at the Yen location. Weekly averages used in Fig. 2d to elucidate the seasonality were between 3.5 and $30 \mathrm{~cm} / \mathrm{s}$. Currents speeds were highest in September/October 2001 and in October 2002-May 2003 and lower $(<15 \mathrm{~cm} / \mathrm{s})$ in January 2001-August 2002. The currents flowed onshore (SE-SW) all through the sampling period which is typical for the deep water of the Kara Sea during most of the year (Harms et al., 2003).

\subsection{Trap Yen 02 and Yen 04}

\subsubsection{Bulk components}

Particle fluxes into the Yen 02 trap were between $20 \mathrm{mg} \mathrm{m}^{-2} \mathrm{~d}^{-1}$ in May 2001 and $12,936 \mathrm{mg} \mathrm{m}^{-2} \mathrm{~d}^{-1}$ in October 2002 (Table 1, Fig. 3a). Lithogenic matter made up between $70 \%$ and $83 \%$ of total material. Biogenic opal contributed between $10 \%$ and $18 \%$ with little seasonal variation. From January to June 2001 biogenic opal could not be determined as samples were on glass fibre filters (see 2.2.) so that we may have missed a small seasonal signal. Organic carbon percentages were between $2.5 \%$ and $17.6 \%$ which is a very wide range compared to other trap experiments in arctic regions (Hargrave et al., 2002; Ingalls et al., 2006; Wassmann et al., 2004). Low values $(<8 \%)$ occurred from February to April, from the end of June to September 2001, and during the whole deployment period of Yen 04. Peaks occurred in May/June 2001, in October 2000 to January 2001, and in May/June 2001. Smaller peaks were observed in mid-July and in the beginning of August 2001. C/N ratios were between 7.6 and 11.7 with higher ratios in June through August 2001 (Table 1). 


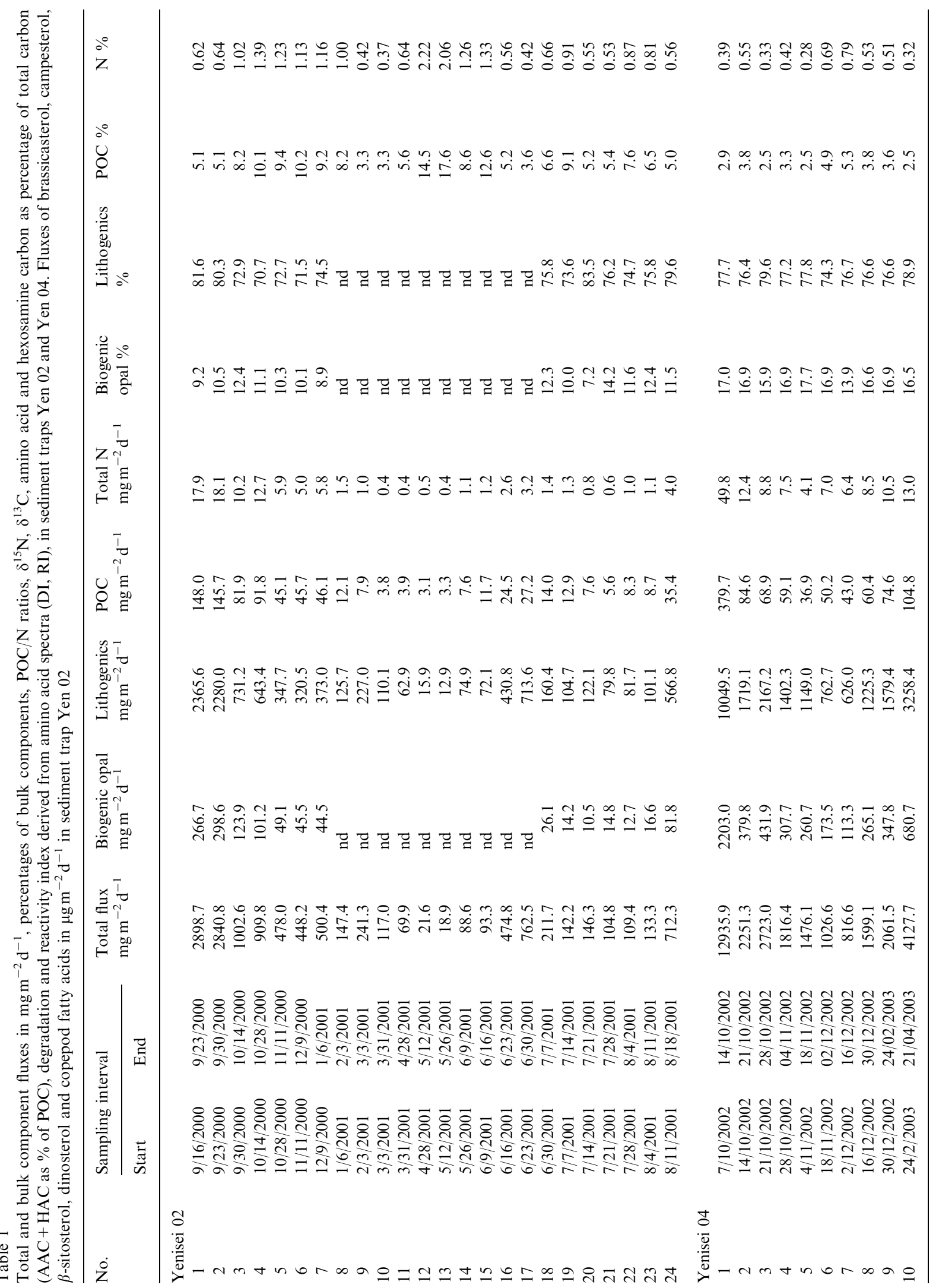




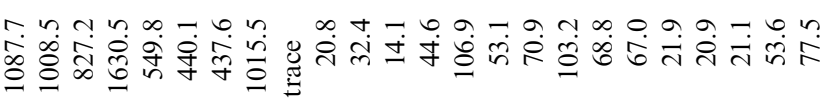

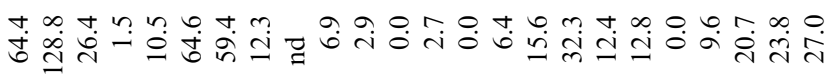

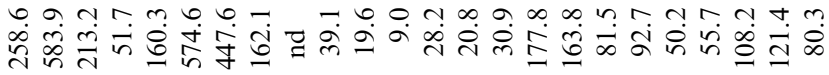

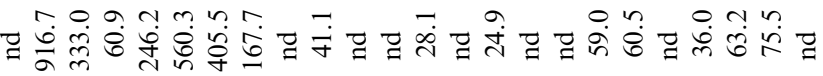

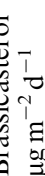
$\bar{x}$ $\bar{a}$

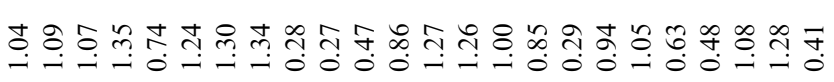

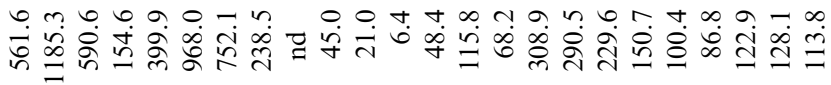

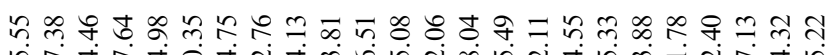

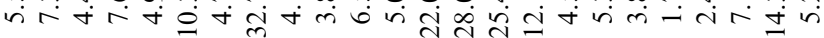

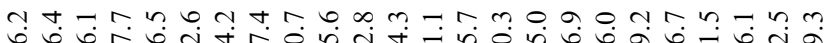

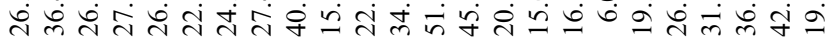

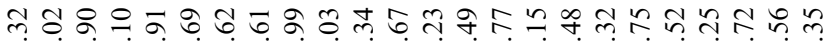

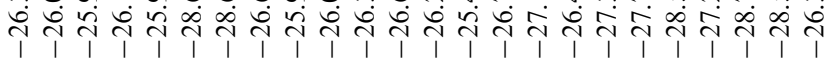

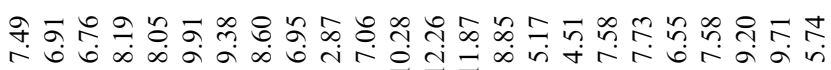

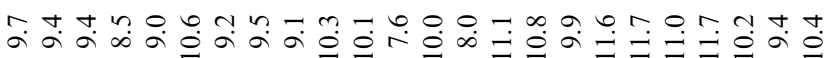
ș ब. के t

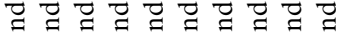

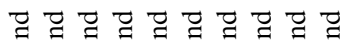

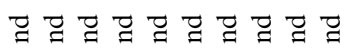

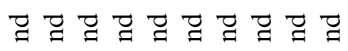

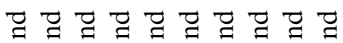

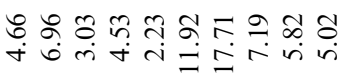

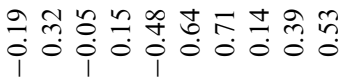
तुํำ

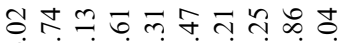

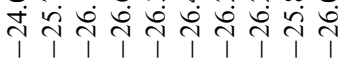

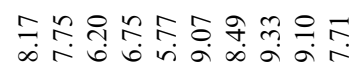

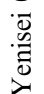


a
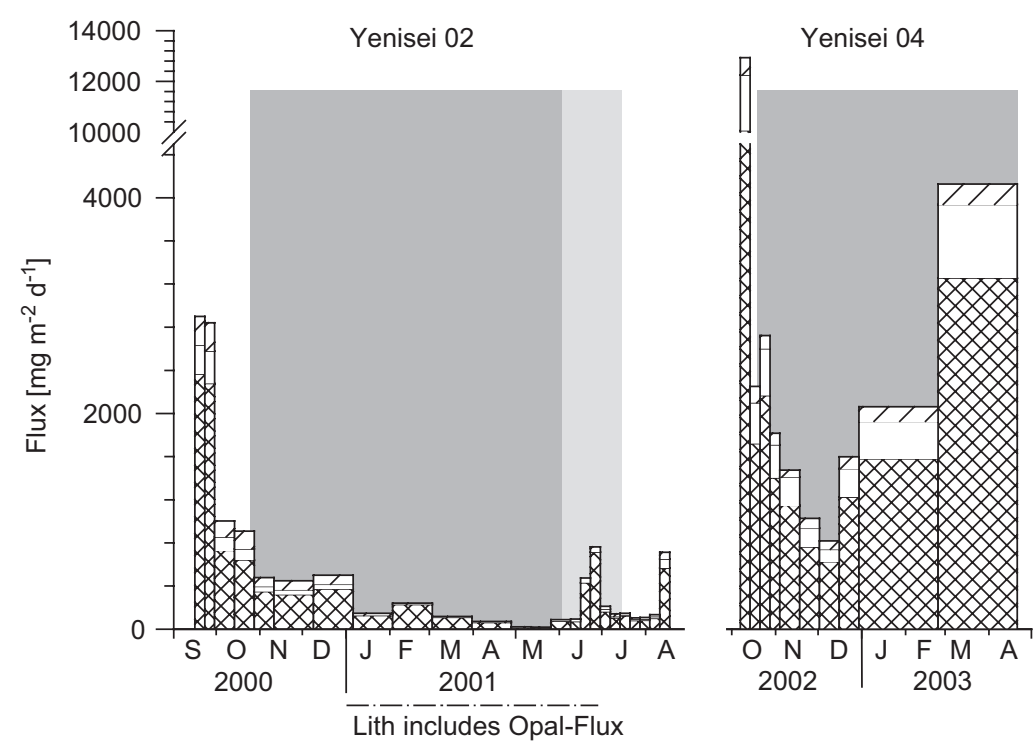

$\square \times x$ Lithogenic Matter Flux Biogenic Opal Flux

b

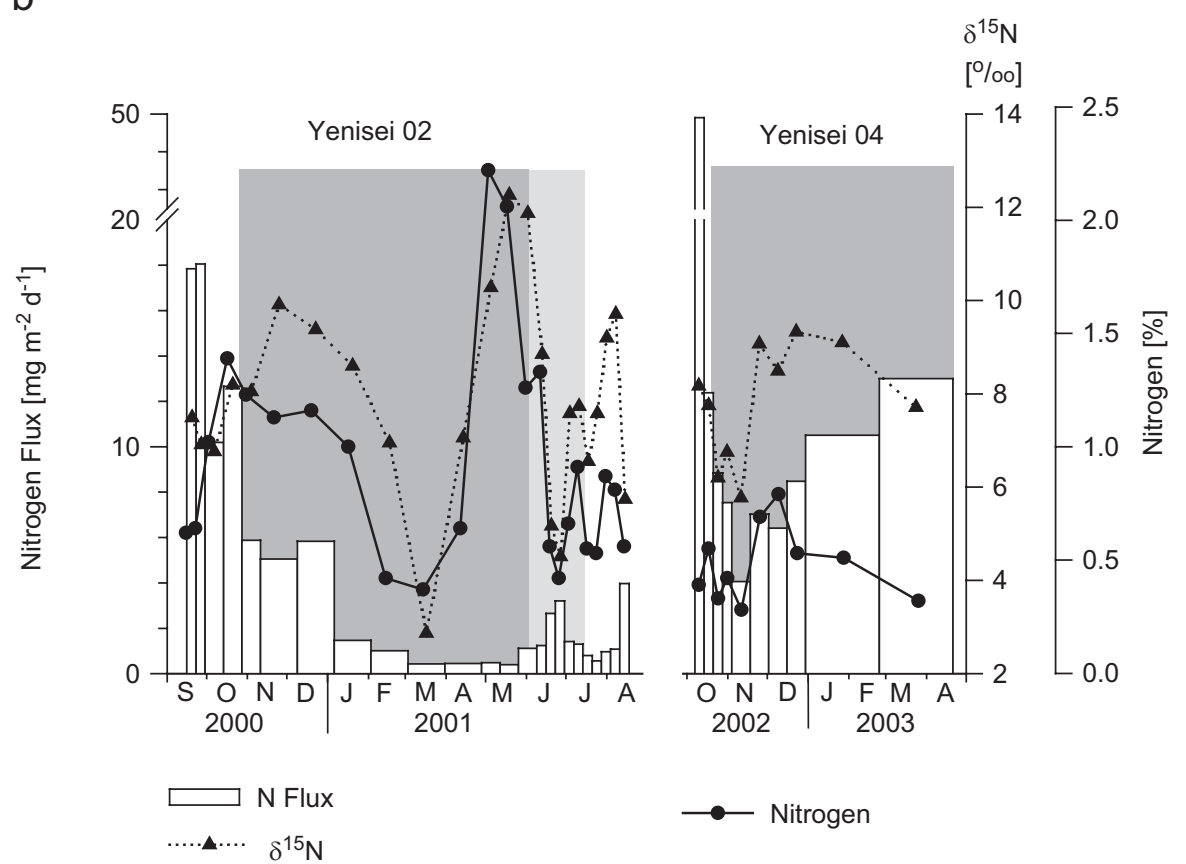

Fig. 3. (a) Bulk component fluxes (lithogenic matter, biogenic opal, organic matter) in $\mathrm{mg} \mathrm{m}^{-2} \mathrm{~d}^{-1}$ sampled by the Yen 02 and 04 traps. In indicated samples (January-June 2001) biogenic opal has not been determined so that hatched areas indicate lithogenic matter and biogenic opal. Dark shaded areas indicate complete ice cover and light shade indicates ice break up. (b) Nitrogen fluxes in $\mathrm{mg} \mathrm{m}^{-2} \mathrm{~d}^{-1}$, nitrogen percentages, and $\delta^{15} \mathrm{~N}$ values in the Yen 02 and 04 trap samples. Dark shaded areas indicate complete ice cover and light shade indicates ice break up. (c) Organic carbon fluxes in $\mathrm{mg} \mathrm{m}^{-2} \mathrm{~d}^{-1}$, organic carbon percentages and $\delta^{13} \mathrm{C}$ values in Yen 02 and 04 samples (upper graph). Amino acid (AA) and hexosamine (HA) fluxes in $\mathrm{mg} \mathrm{m}^{-2} \mathrm{~d}^{-1}, \mathrm{~F} 1$ scores of factor analysis of trap samples, and Asp/ß-Ala ratios in Yen 02 and 04 samples (lower graph). Dark shaded areas indicate complete ice cover and light shade indicates ice break up. 
C
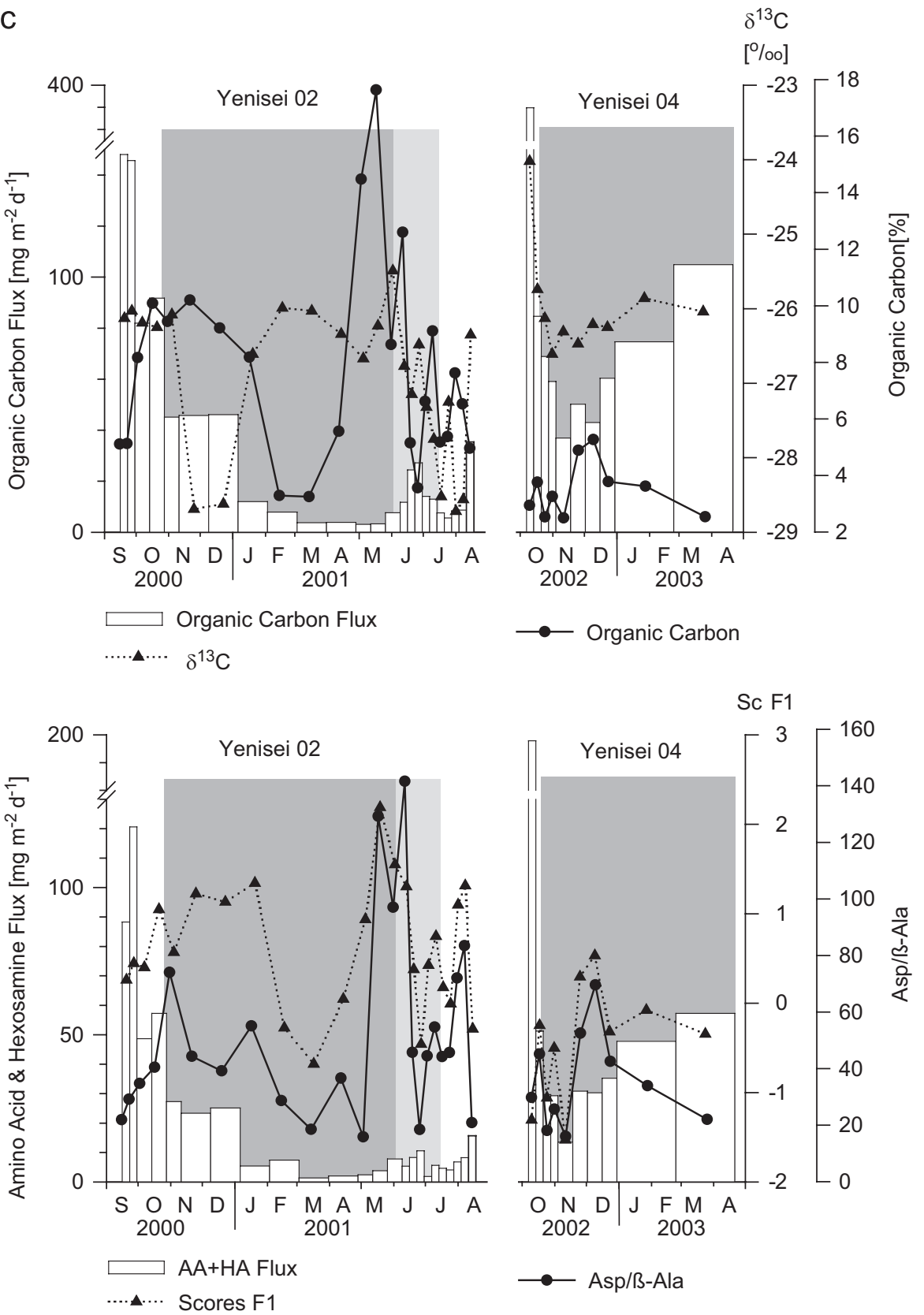

Fig. 3. (Continued)

3.2.2. Stable isotopes, AA, hexosamines, sterols and fatty acids

The $\delta^{15} \mathrm{~N}$ values revealed a very wide range from $2.9 \%$ to a maximum of $12.3 \%$ (Fig. $3 \mathrm{~b}$ ) and were positively correlated with organic carbon and total nitrogen percentages $\left(R^{2}=0.41\right.$ and $R^{2}=0.46$, respectively, $n=34)$. The correlation of AA content and $\delta^{15} \mathrm{~N}$ was even better $\left(R^{2}=0.50\right)$ implying that common processes enhanced both $\delta^{15} \mathrm{~N}$ values and (nitrogenous) organic matter contents. The correlations became more significant if the last four samples of Yen 04 were excluded.

$\delta^{13} \mathrm{C}$ variations differed from those of $\delta^{15} \mathrm{~N}$, and organic contents during most of the year (Fig. $3 b$ 
Table 2

Annual averages of total and bulk component fluxes, weighed means of POC/N ratios, $\delta^{15} \mathrm{~N}, \delta^{13} \mathrm{C}$ and annual averages of percentages of bulk components, DI and RI in sediment trap samples from Yen 02, Yen 04 and Kara Sea 01

\begin{tabular}{|c|c|c|c|c|c|c|c|c|}
\hline & $\begin{array}{l}\text { Yenisei } 02 \\
09 / 00-08 / 01\end{array}$ & $\begin{array}{l}\text { Yenisei } 04 \\
10 / 02-04 / 03\end{array}$ & $\begin{array}{l}\text { BP 00-14 } \\
\text { Surface Sed. }\end{array}$ & $\begin{array}{l}\text { BP 99-04 } \\
\text { Surface Sed. }\end{array}$ & $\begin{array}{l}\text { BP } 00-07 \\
\text { Surface Sed. }\end{array}$ & $\begin{array}{l}\text { Kara Sea } 01 \\
09 / 01-08 / 02\end{array}$ & $\begin{array}{l}\text { BP } 00-26 \\
\text { Surface Sed. }\end{array}$ & $\begin{array}{l}\text { BP 01-61 } \\
\text { Surface Sed. }\end{array}$ \\
\hline Latitude N & $74^{\circ} 00,28$ & $74^{\circ} 00,1145$ & $72^{\circ} 55,86$ & $73^{\circ} 24,9$ & $74^{\circ} 39,48$ & $76^{\circ} 12,08$ & $75^{\circ} 42,54$ & $76^{\circ} 12,9$ \\
\hline Longitude E & $80^{\circ} 00,45$ & $80^{\circ} 19,6413$ & $79^{\circ} 47,4$ & $79^{\circ} 40,5$ & $81,08,46$ & $75^{\circ} 45,3$ & $77^{\circ} 57,6$ & $75^{\circ} 53,15$ \\
\hline Water depth $\mathrm{m}$ & 31 & 40 & 19.2 & 32.3 & 38 & 73 & 68 & 106 \\
\hline Trap depth m & 20 & 29 & & & & 54 & & \\
\hline Total flux $\mathrm{g} \mathrm{m}^{-2} \mathrm{a}^{-1}$ & 150.3 & $547.1^{\mathrm{a}}$ & 650 & 500 & 350 & 222.3 & 170 & 70 \\
\hline $\begin{array}{l}\text { Lithogenic flux } \\
\mathrm{g} \mathrm{m}^{-2} \mathrm{a}^{-1}\end{array}$ & 118.7 & $425.9^{\mathrm{a}}$ & 553.2 & 441.0 & 301.7 & 192.0 & 148.8 & nd \\
\hline Opal flux $\mathrm{g} \mathrm{m}^{-2} \mathrm{a}^{-1}$ & 12.6 & $91.1^{\mathrm{a}}$ & 66.3 & 42.5 & 34.3 & 15.6 & 15.5 & nd \\
\hline POC flux $\mathrm{g} \mathrm{m}^{-2} \mathrm{a}^{-1}$ & 10.6 & $16.7^{\mathrm{a}}$ & 13.0 & 7.8 & 2.6 & 8.2 & 2.7 & 0.7 \\
\hline $\mathrm{N}$ flux $\mathrm{g} \mathrm{m}^{-2} \mathrm{a}^{-1}$ & 1.30 & $2.21^{\mathrm{a}}$ & 1.40 & 0.95 & 0.35 & 1.17 & 0.36 & 0.12 \\
\hline $\mathrm{C} / \mathrm{N}$ (atomic) & 9.5 & 8.8 & 11.1 & 9.5 & 8.8 & 8.2 & 8.8 & 6.9 \\
\hline$\delta^{15} \mathrm{~N} \%$ & 7.99 & 8.21 & 5.28 & 5.70 & 6.99 & 7.47 & 7.05 & 6.98 \\
\hline$\delta^{13} \mathrm{C} \%$ & -26.88 & -25.77 & -26.96 & -26.37 & -26.15 & -24.12 & -24.92 & -24.39 \\
\hline Lithogenic matter \% & 79.0 & 77.9 & 85.0 & 88.2 & 86.2 & 86.4 & 87.5 & nd \\
\hline Biogenic opal \% & 8.4 & 16.7 & 11.0 & 8.5 & 9.8 & 7.0 & 9.1 & nd \\
\hline POC $\%$ & 7.1 & 3.1 & 2.0 & 1.6 & 0.8 & 3.7 & 1.6 & 1.0 \\
\hline $\mathrm{N} \%$ & 0.87 & 0.40 & 0.21 & 0.19 & 0.10 & 0.52 & 0.21 & 0.17 \\
\hline DI & 0.90 & 0.22 & nd & -0.53 & -0.81 & -0.05 & -1.19 & nd \\
\hline RI & 9.57 & 6.91 & nd & 1.51 & 1.01 & 5.43 & 0.21 & nd \\
\hline
\end{tabular}

For Yen 02 and Kara Sea 01 fluxes have been extrapolated to one year based on average fluxes of 11 months. For trap Yen 04 fluxes have been averaged for the 195.5 days of deployment.

Accumulation rates in surface sediments (0-2 ka) taken from Table 7.6.2. in Stein and Fahl (2004) and accumulation rates of lithogenic matter, biogenic opal, organic carbon (POC) and nitrogen $(\mathrm{N})$ calculated rom our bulk component measurements and total accumulation rates. POC/N ratios, $\delta^{15} \mathrm{~N}, \delta^{13} \mathrm{C}$, percentages of bulk components, DI and RI in surface sediments.

${ }^{\mathrm{a}} \mathrm{g} \mathrm{m}^{-2} 195.5 \mathrm{~d}^{-1}$.

and c). Minima occurred in November/December 2000 and June to August 2001. The weighted annual averages in Yen 02 (Yen 04) were 8.0\%o (8.2\%o) and $-26.9 \%$ (-25.8\%o) for $\delta^{15} \mathrm{~N}$ and $\delta^{13} \mathrm{C}$, respectively (Table 2). AA carbon contributed $15-40 \%$ to total organic carbon and AA nitrogen contributed $40-95 \%$ to total nitrogen and had maximum values in May/June and August 2001.

All sterol fluxes (brassicasterol, dinosterol, $\beta$-sitosterol and campesterol) showed similar seasonal patterns that are correlated to those of other organic components (Table 1). Flux maxima occurred in September and in the beginning of October 2001 as well as during November/December 2000 when the maximum concentrations were attained. A third but lower maximum was found in June/ August 2001. The fluxes of brassicasterol and campesterol showed values from 10 to more than $1000 \mu \mathrm{g} \mathrm{m}^{-2} \mathrm{~d}^{-1}$, whereas the fluxes of $\beta$-sitosterol and dinosterol were lower with maxima of 500 and $130 \mu \mathrm{g} \mathrm{m}^{-2} \mathrm{~d}^{-1}$, respectively (Table 1 ). The highest fluxes of the 20:1 and 22:1 fatty acids (both isomers) occurred from October 2000 to January 2001, reaching rates of $1600 \mu \mathrm{g} \mathrm{m}^{-2} \mathrm{~d}^{-1}$. During the other months of the year these values were distinctly lower $(1 / 10-1 / 100)$.

\subsection{Trap Kara 01}

\subsubsection{Bulk components}

Particle fluxes at the Kara 01 location were between $80 \mathrm{mg} \mathrm{m}^{-2} \mathrm{~d}^{-1}$ in September 2001 and $1320 \mathrm{mg} \mathrm{m}^{-2} \mathrm{~d}^{-1}$ in July/August 2002. Maxima occurred in January/February and August and minima in the first cup (September) and in April to mid-June (Table 3; Fig. 4a). Except for the first cup that had exceptionally high organic carbon contents of almost $22 \%$, the composition of the material was very similar in all cups. Lithogenic matter contents were between $81 \%$ and $90 \%$, biogenic opal contents were $6-8 \%$ and organic carbon contents $2.4-6.5 \%$ (Table 3). Maxima of organic carbon contents occurred in September/ October 2001 and in June-August 2002 and were accompanied by minima of lithogenic matter contents. $\mathrm{C} / \mathrm{N}$ ratios were between 6.7 and 9.7. 


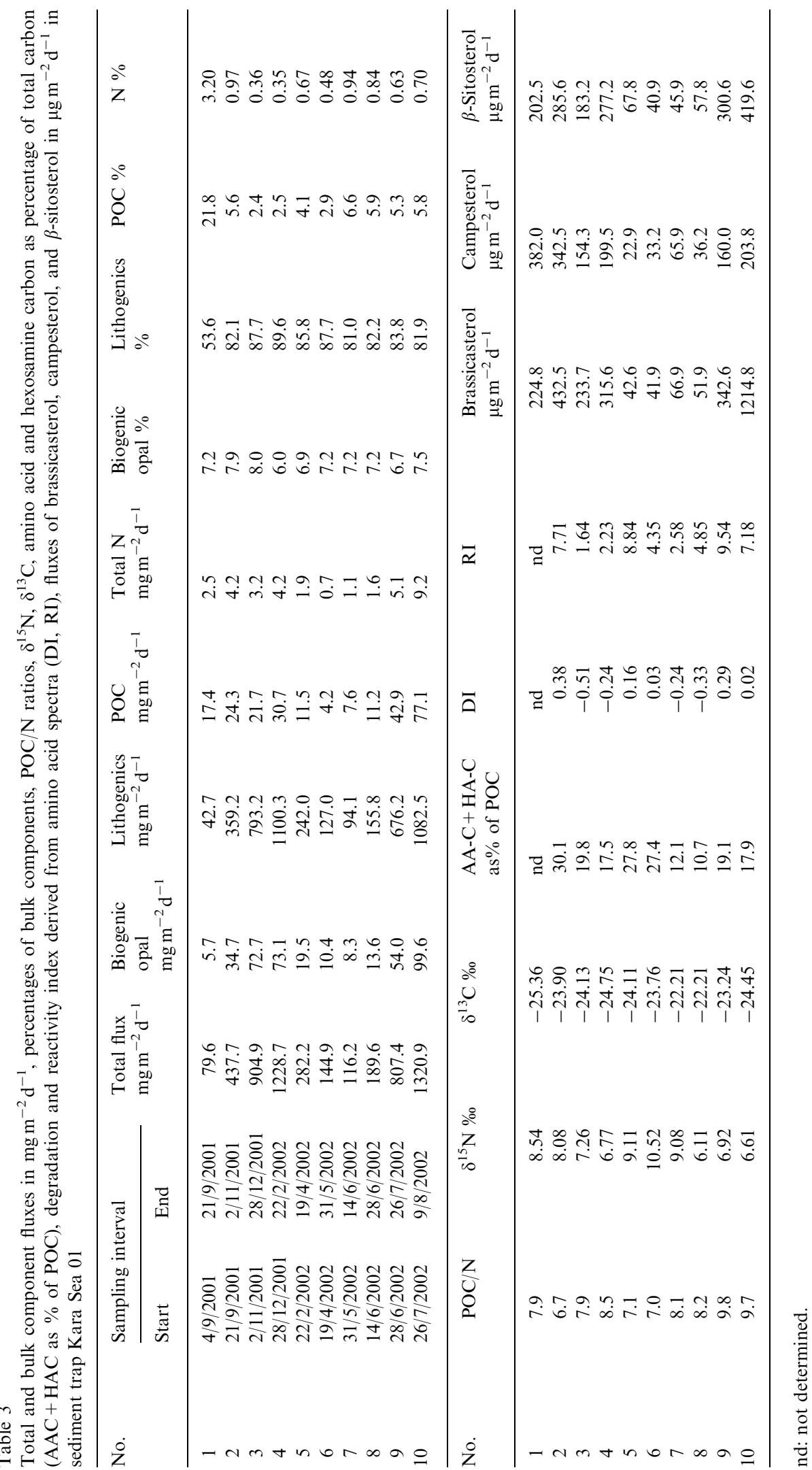


3.4.2. Stable isotopes, AA, hexosamines, sterols and fatty acids

The $\delta^{15} \mathrm{~N}$ values of the Kara 01 samples were between $6.6 \%$ and $10.5 \%$; highest values occurred in the low flux period from March to the beginning of June (Fig. $4 \mathrm{~b}$ ). $\quad \delta^{13} \mathrm{C}$ values were between $-22.2 \%$ and $-25.4 \%$ and had their maximum in May/June (Fig. 4c). Weighted mean values of the whole deployment were $7.5 \%$ and $-24.1 \%$ for $\delta^{15} \mathrm{~N}$ and $\delta^{13} \mathrm{C}$, respectively (Table 2). AA and

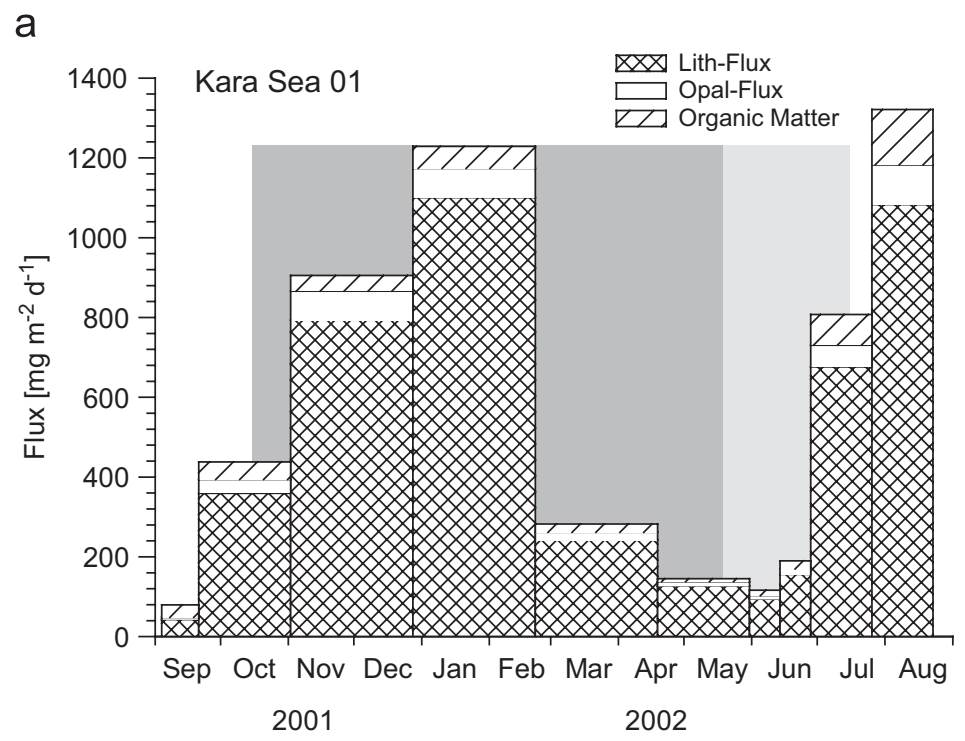

b

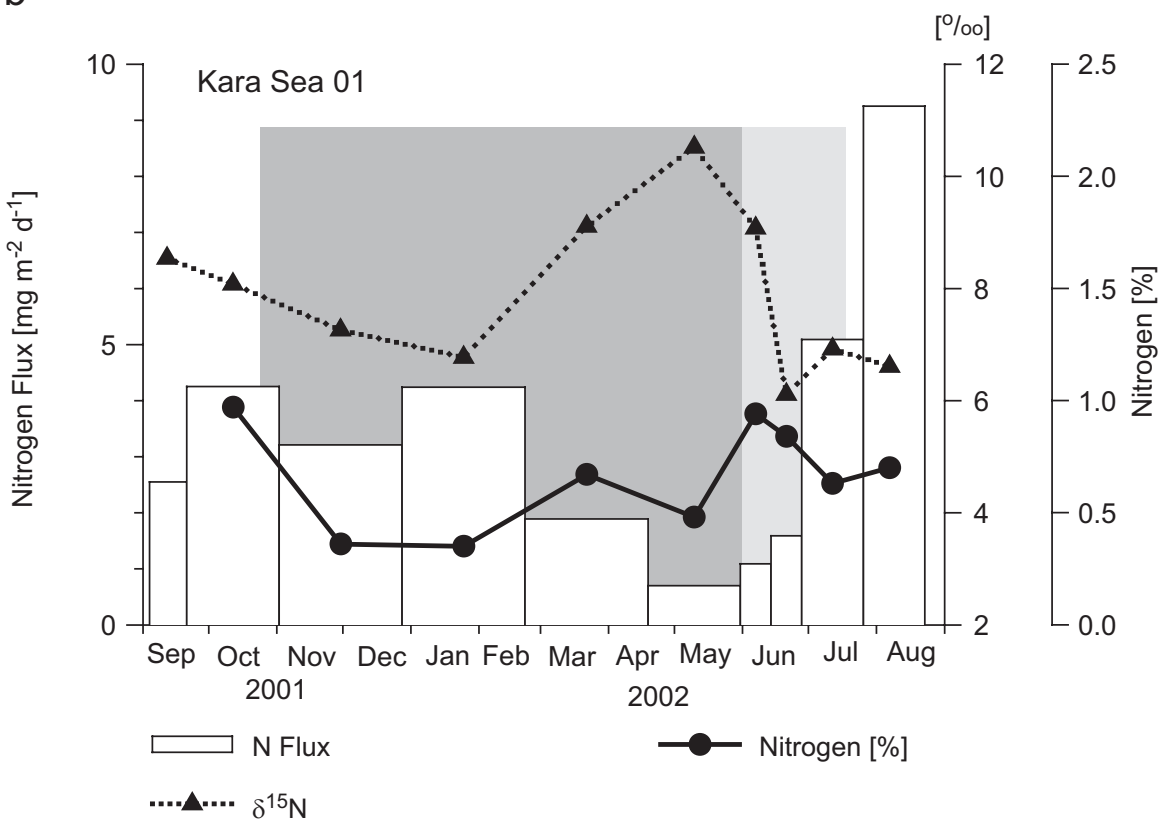

Fig. 4. (a) Bulk component fluxes (lithogenic matter, biogenic opal, organic matter) in $\mathrm{mg} \mathrm{m}^{-2} \mathrm{~d}^{-1}$ sampled by the Kara Sea 01 trap. Dark shaded area indicates complete ice cover and light shade indicates ice break up. (b) Nitrogen fluxes in $\mathrm{mg} \mathrm{m}^{-2} \mathrm{~d}^{-1}$, nitrogen percentages, and $\delta^{15} \mathrm{~N}$ values in the Kara Sea 01 trap samples. Dark shaded area indicates complete ice cover and light shade indicates ice break up. (c) Organic carbon fluxes in $\mathrm{mg} \mathrm{m}^{-2} \mathrm{~d}^{-1}$, organic carbon percentages and $\delta^{13} \mathrm{C}$ values in Kara Sea 01 samples (upper graph). Amino acid and hexosamine fluxes in $\mathrm{mg} \mathrm{m}^{-2} \mathrm{~d}^{-1}, \mathrm{~F} 1$ scores of factor analysis of trap samples, and Asp/B-Ala ratios in Kara Sea 01 samples (lower graph). Dark shaded area indicates complete ice cover and light shade indicates ice break up. 

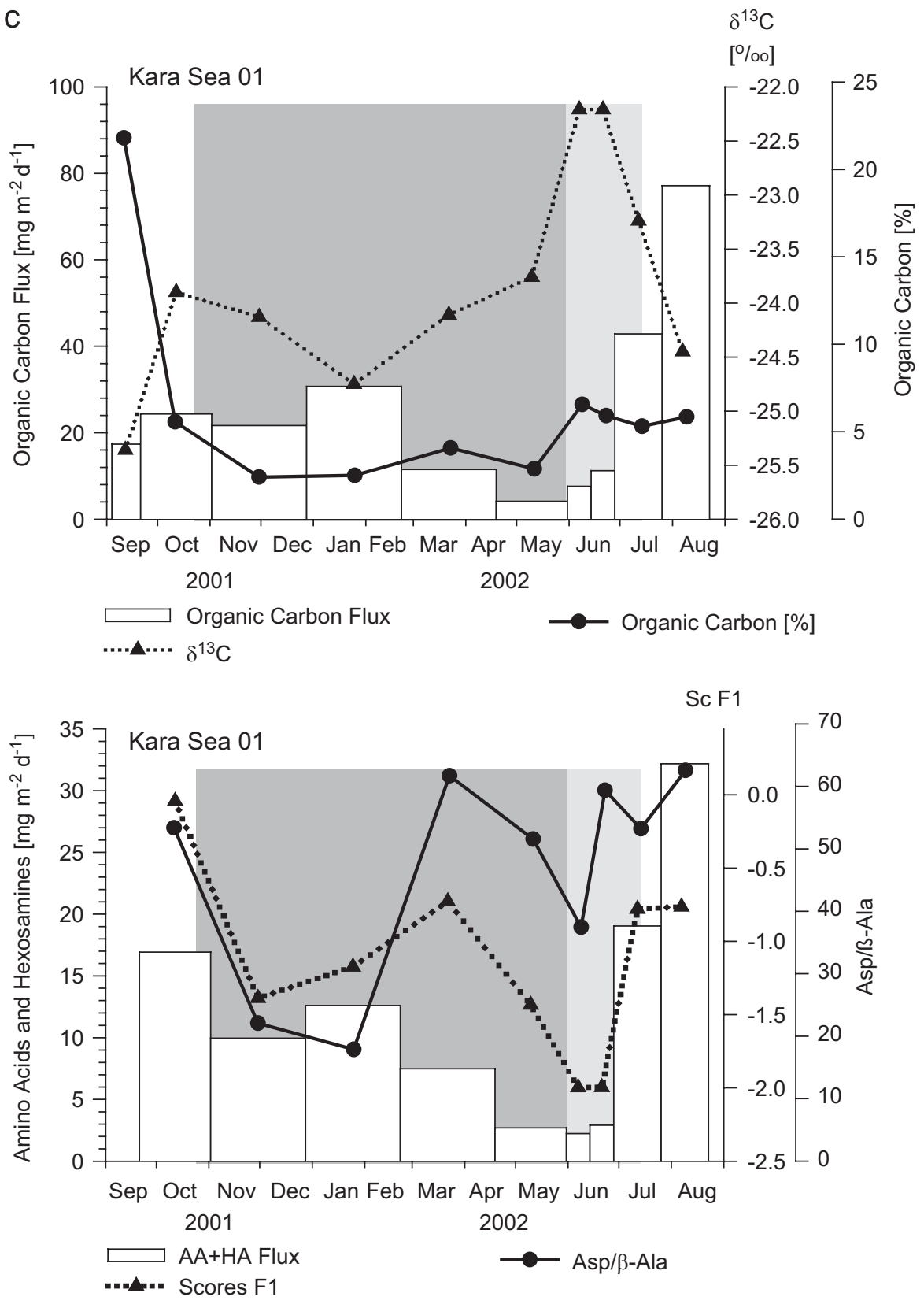

Fig. 4. (Continued)

hexosamines contributed $11-30 \%$ to total organic carbon and $23-55 \%$ to total nitrogen. Minima corresponded with the high $\delta^{13} \mathrm{C}$ values in June. Unlike the Yenisei samples there were no significant correlations among the measured variables.

Campesterol and $\beta$-sitosterol had nearly the same flux pattern throughout the year with high fluxes of up to $400 \mu \mathrm{g} \mathrm{m}^{-2} \mathrm{~d}^{-1}$ except from March to June (Table 3). The brassicasterol fluxes reached values around $300 \mu \mathrm{g} \mathrm{m}^{-2} \mathrm{~d}^{-1}$ from September 2001 to February 2002 and a flux maximum of $1200 \mu \mathrm{g} \mathrm{m}^{-2} \mathrm{~d}^{-1}$ in September 2002 (Table 3). The bassicasterol pattern nearly paralleled the record of organic carbon flux. No dinosterol could be detected and the fatty acid (20:1 and 22:1) contents were rather low, reaching not more than trace amounts in some months and are, therefore, not given. 


\section{Discussion}

\subsection{Relation of fluxes to ice cover, light availability and river discharge}

Particle fluxes at both trap locations had maxima during the ice free as well as the ice covered seasons (Fig. 2c) which is in contrast to other studies from seasonally ice covered regions (Hargrave et al., 2002; Honjo et al., 2000; Ingalls et al., 2006; Ramseier et al., 1997; Wassmann et al., 2004). The high river discharge by the Yenisei in June and the $\mathrm{Ob}$ in June to August (Fig. 2a) was reflected in only slightly enhanced fluxes during these months (Fig. 2c). This could imply that much of the riverine particulate matter was kept in suspension during the summer months and settled later in the year (4.3.2.). Sufficient light to initiate a plankton bloom ( $>15 \mathrm{~W} \mathrm{~m}^{-2}$; Gowen et al., 1995) was available from March to September. The ice cover as well as the high concentration of suspended matter from the rivers, however, probably prevented an intense bloom with enhanced particle fluxes in early spring and summer (see 4.3.2.).

The pattern of current speeds (Fig. 2d) did not correspond with the particle flux pattern (Fig. 2c). This would be the case if we had a strong sampling artefact due to overtrapping in periods of high current speeds (Gust et al., 1992; Gust and Kozerski, 2000). We can thus exclude that the flux was significantly modulated by current related changes in sampling efficiency.

\subsubsection{Sources and degradation of organic matter in the Kara Sea: Stable isotopes}

$\delta^{13} \mathrm{C}$ values were used in previous studies to quantify terrestrial input into the Kara Sea (Fernandes and Sicre, 1999; Krishnamurthy et al., 2001) as well as into other Arctic shelf seas (Goni et al., 2005; Guo et al., 2004a, 2004b). Highest $\delta^{13} \mathrm{C}$ values measured in our study were about $-22 \%$ (Tables 1 and 3 ). This was lighter than the marine end member in lower latitudes due to the better $\mathrm{CO}_{2}$ dissolution in colder water (Sackett et al., 1974). River sediments had minima of $\delta^{13} \mathrm{C}$ around $-29 \%$ in the $\mathrm{Ob}$ and $-27 \%$ in the Yenisei (Fahl et al., 2003; Nagel et al., submitted) which was close to Kara Sea terrestrial end member $\delta^{13} \mathrm{C}$ values of $-27.8 \%$ and $-27 \%$ used by Fernandes and Sicre (1999) and Krishnamurthy et al. (2001), respectively. The $\delta^{13} \mathrm{C}$ of trap samples showed a wide range. Average $\delta^{13} \mathrm{C}$ values at the Yen locations were closer to the terrestrial end member whereas the average $\delta^{13} \mathrm{C}$ of Kara 01 samples was closer to marine and estuarine phytoplankton (Table 2; Fig. 5).

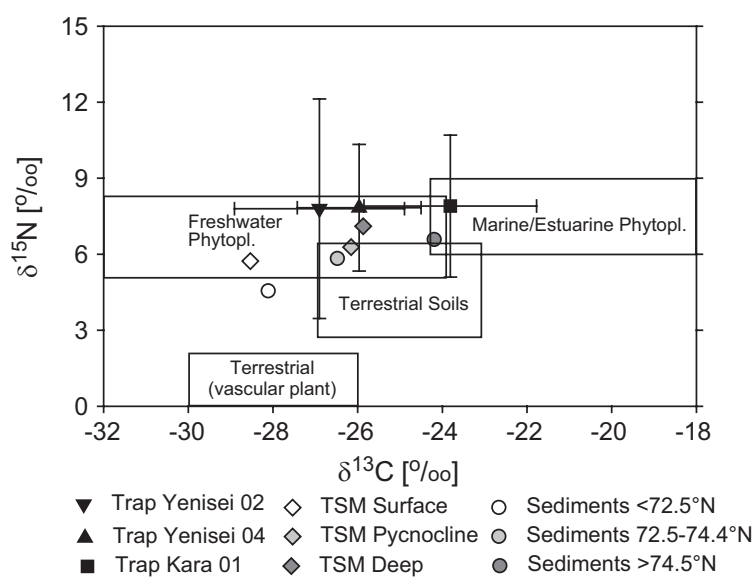

Fig. 5. Mean values and standard deviations of $\delta^{13} \mathrm{C}$ vs. $\delta^{15} \mathrm{~N}$ in sediment trap samples from the Yen 02, 04 and Kara Sea 01 stations. Ranges for freshwater phytoplankton, marine/estuarine plankton, terrestrial soils and vascular plant (after McCallister et al., 2004) are indicated. Also indicated are mean values in TSM and sediments from the Kara Sea (after Nagel et al., submitted).

Terrigenous organic matter in the Kara Sea can also be identified by low $\delta^{15} \mathrm{~N}$ values. The terrestrial end member $\delta^{15} \mathrm{~N}$ values are around $4.5 \%$ in the $\mathrm{Ob}$ and less than 3\% in the Yenisei, respectively (Nagel et al., submitted). Investigations of Guo et al. (2004a) showed that the $\delta^{15} \mathrm{~N}$ in Siberian river sediments decrease from west to east. This is probably related to the eastward increase in permafrost area and thickness (Stolbovoi and McCallum, 2002) which could lead to a better preservation of soil organic matter. As will be shown below (4.3.) the periods of maximum river discharges to the Kara Sea could be discerned from both, low $\delta^{13} \mathrm{C}$ and $\delta^{15} \mathrm{~N}$ values in trap material.

Surface sediments showed a characteristic increase of $\delta^{13} \mathrm{C}$ and $\delta^{15} \mathrm{~N}$ towards the north, similar to average trap values, reflecting a change from terrestrial to marine dominance (Fig. 5). The northern Kara Sea sediments had $\delta^{15} \mathrm{~N}$ values of more than $7 \%$ which is about $2 \%$ higher than average marine nitrate (Sigman et al., 2000) but similar to other sediments from the Arctic Ocean (Schubert and Calvert, 2001). Suspended matter had a more terrestrial signal in surface waters and a marine imprint at depth which could be due to the onshore flow of deep water as well as the resuspension of sediments (Nagel et al., submitted).

Most $\delta^{15} \mathrm{~N}$ of trap samples were higher than those of phytoplankton end members, suspended matter and surface sediments. There are several possible explanations for these higher values. $\delta^{15} \mathrm{~N}$ may 
reflect not only organic matter sources but also transformation processes within the nitrogen cycle (Altabet, 1996). Isotopic fractionation during nitrogen uptake results in an increase of the $\delta^{15} \mathrm{~N}$ of the substrate as well as the produced organic matter as nutrients become depleted during a progressing plankton bloom (Altabet, 1996). This process may explain the high $\delta^{15} \mathrm{~N}$ values of Yenisei samples from an early plankton bloom in the polynya area (see 4.3.). High $\delta^{15} \mathrm{~N}$ values can also indicate the contribution from zooplankton as well as their fecal pellets as each increase in trophic level is accompanied by a $\delta^{15} \mathrm{~N}$ increase by about 3-4\% (Montoya et al., 1991). This may be responsible for high $\delta^{15} \mathrm{~N}$ values of autumn and winter samples from the Yenisei location (see 4.3.). Finally, $\delta^{15} \mathrm{~N}$ values can increase during diagenesis of sinking particles and sediments due to organic matter degradation (Altabet et al., 1999; Lourey et al., 2003; Smith et al., 2002). However, a strong isotopic imprint is probably restricted to degradation processes in the deep sea; near shore and slope sediments showed no significant $\delta^{15} \mathrm{~N}$ increase in sediments compared to sinking particles which was probably related to faster burial and oxygen depletion in the sediments (Altabet et al., 1999; Gaye-Haake et al., 2005). Kara Sea trap samples with higher $\delta^{15} \mathrm{~N}$ values were, generally, less degraded (see 3.2. and 4.3.) so that differences in nitrogen sources and increasing trophic levels may be responsible for higher $\delta^{15} \mathrm{~N}$ values in the Kara Sea rather than organic matter degradation.

\subsubsection{Sources and degradation of organic matter in} the Kara Sea: $A A$

AA are among the more labile organic constituents and serve as a major food source to heterotrophs. In order to study the factors responsible for changes in AA composition we carried out a factor analysis on 18 normalized $\mathrm{mol} \%$ values of amino acids measured in a set of 213 samples from the Kara Sea. These consist of three samples from the fresh water end member, three soil and root samples, 102 suspended matter samples from the estuaries to the open marine environment, 62 surface sediment samples and 43 sediment trap samples (see Tables 1 and 3). Similar to the results of other studies (Dauwe and Middelburg, 1998; Ingalls et al., 2003) the AA enriched in fresh plankton have highest component scores for factor 1 (F1) whereas the amino acids enriched during organic matter degradation have higher component scores for factor 2 (F2). Generally, the component loadings for F1 are similar to those of Dauwe et al. (1999) used for the calculation of the DI. In order to classify the Kara Sea trap samples according to their state of degradation we plotted the RI (see 2.4.4.) of Kara Sea samples against their site scores for F1 (Fig. 6) which is very similar to the RI-DI plot of Unger et al. (2005). It elucidates the large variations of degradation states of trap samples ranging from values typical of fresh surface suspension to those of surface sediments. Organic matter of the Yen 02 trap is, mostly, in the range of surface suspension whereas Yen 04 and Kara 01 samples are more similar to deep suspension; the low RI and F1 site scores of some of their samples may even indicate contribution from resuspended sediments. River suspension of the Yenisei sampled in September is in the range of brackish and marine surface suspension whereas samples taken during the peak discharge period in June from Salekhard on the $\mathrm{Ob}$ are more degraded (Fig. 6). This could be due to the addition of soil organic matter to the $\mathrm{Ob}$ suspension which degradation state is close to that of deep suspended matter (Fig. 6).

Dauwe et al. (1999) pointed out that the changes in the monomer distribution determining the DI are not always linear with increasing degradation. This is confirmed by our study that shows that the major changes in the RI occur in relatively fresh organic matter having high RI and F1 scores, whereas the major differences in F1 scores occur between the more degraded trap samples and sediments. The F1 site score-RI plot, thus, helps to classify samples of

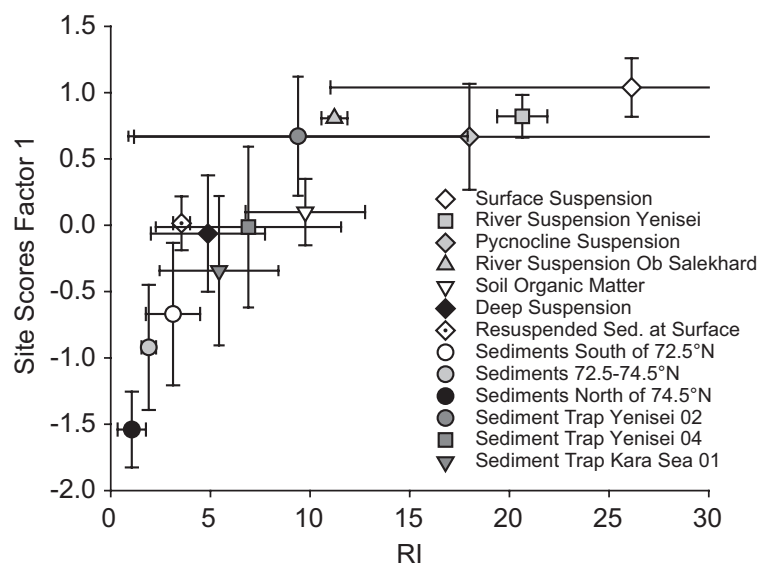

Fig. 6. The amino acid derived reactivity index (RI) plotted against the $\mathrm{F} 1$ scores of a factor analyzes of $\mathrm{mol} \%$ amino acids of a set of 213 samples from the Kara Sea. Mean values and standard deviations are given for suspended matter of different depths, river end members, soils samples, sediments from different latitudes and the three trap deployments. 
variable environments according to their state of degradation.

\subsection{Seasonal variations}

\subsubsection{Factor analyses of trap samples}

A second factor analysis was carried out on the trap samples only, using the mol\% of 18 AA, organic carbon, nitrogen, and $\mathrm{AA}+$ hexosamine contents, the DI, RI, $\delta^{15} \mathrm{~N}$ and $\delta^{13} \mathrm{C}$. The AA enriched in fresh organic matter (Arg, Val, Lys, Ile, Leu, Phe, His, Tyr), organic carbon, nitrogen and $\mathrm{AA}+$ hexosamine contents as well the indicators of organic matter freshness DI and RI have high component scores for F 1 (Fig. 7a). Moreover, $\delta^{15} \mathrm{~N}$ is associated with this group of variables indicating that organic matter of a less degraded source in Kara Sea trap samples is characterised by higher $\delta^{15} \mathrm{~N}$ values.

The second group of variables has lower F1 and higher F2 scores and includes the AA enriched by degradation such as $\beta$-Ala, $\gamma$-Aba, Orn and Gly (Fig. 7a) as well as Ala, Met, Ser and Thr. Of these Ser and Thr are, generally assumed to be enriched in diatoms together with Gly (Hecky et al., 1973; Ingalls et al., 2006). Ser, Thr and Gly may, therefore be considered as a separate third group of amino acids associated with biogenic opal (Ingalls et al., 2006).

A fourth group has low F1 and F2 scores and includes Asp and Glu as well as $\delta^{13} \mathrm{C}$. Very similar results were obtained by Ingalls et al. (2006) in their PCA carried out on trap samples from the Southern Ocean using AA and pigments. They attributed the separation of Asp and Glu to the association of these AA with carbonaceous organisms. However, the Kara Sea samples had calcium carbonate contents below the detection limit of carbonate measurements so that we can exclude this source. The association of the acidic AA with $\delta^{13} \mathrm{C}$ implies that they indicate marine vs. terrestrial material. The AA spectra from the Kara Sea trap samples thus reflect, both, organic matter degradation as well as organic matter sources.

The factor scores for F1 and F2 for trap samples show that samples from the Yenisei location mainly differ in their state of degradation (Fig. 7b). Less degraded material characterised by high $\mathrm{F} 1$ and low F2 scores is mostly from the autumn and early spring samples of the Yenisei 02 deployment while the most degraded samples with low F1 and high F2 scores are those with the highest contribution of a

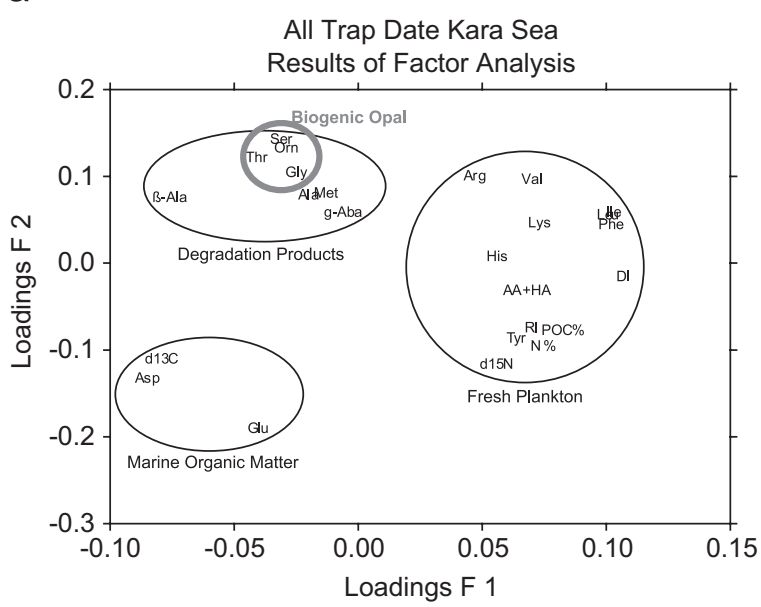

b

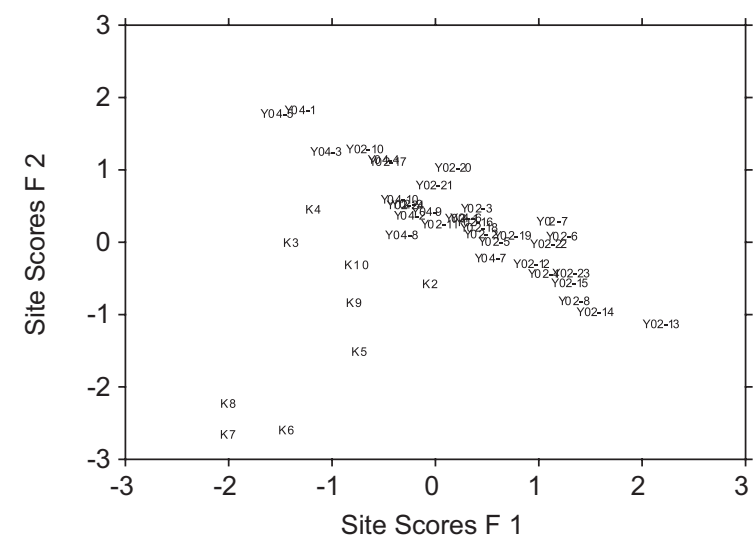

Fig. 7. (a) Variable loadings for factor 1 (F1) and factor 2 (F2) of a factor analysis of $\mathrm{mol} \%$ amino acids, $\delta^{13} \mathrm{C}(\mathrm{d} 13 \mathrm{C}), \delta^{15} \mathrm{~N}$ $(\mathrm{d} 15 \mathrm{~N})$, nitrogen $\%(\mathrm{~N} \%)$, organic carbon \% (POC \%), amino acid and hexosamine in $\mathrm{mg} / \mathrm{g}$ (AA + HA), the RI and the DI. The compounds are divided into four groups: "fresh plankton", "degradation products", "biogenic opal" and indicators of "marine organic matter". Gly is part of the "biogenic opal" and "degradation products" group; Met and Ala cannot be considered as degradation indicators but for unknown reasons plot within the latter group. (b) Site scores of F1 and F2 of individual trap samples from the Yenisei 02 (Y02), Yenisei 04 (Y04) and Kara Sea (K) deployments.

resuspended sediments from the ice covered season of the Yen 04 deployment. In contrast to the Yen samples the Kara samples have lower F1 and F2 scores revealing the more marine organic matter source rather than the state of degradation.

\subsubsection{Seasonality of fluxes at Yen 02 and 04}

4.3.2.1. Ice-free period in autumn. Highest particle fluxes of both trap deployments occurred in September/October just before ice formation started 
(Figs. 3a and 8) and were in the same order of magnitude as late summer/early autumn fluxes in other arctic coastal seas (Wassmann et al., 2004). Intermediate organic carbon and nitrogen percentages and organic matter quality indicate mixed planktonic and fluvial organic matter source (Figs. 3b, c and 8). This is confirmed by intermediate $\delta^{15} \mathrm{~N}$ values and microscopic investigations of Nöthig (2005, personal communication). Ice-free conditions and better light availability due to less river input allowed increased primary productivity in autumn and at the same time promoted enhanced settling of river material which was partly still in suspension in autumn. Short-term trap deployments and suspended matter sampling identified an intense plankton bloom off the $\mathrm{Ob}$ estuary in September 1999 (Nöthig et al., 2003; Gaye-Haake et al., 2003). However, in the subsequent years no such blooms were found (Unger et al., 2005). This shows that hydrographic conditions during the ice-free season were spatially and temporally very variable related to atmospheric forcing, i.e. changing wind conditions and pulsed river input so that productivity was patchy and changed rapidly.

\subsubsection{Ice covered season. In mid- to the end of} October as the Kara Sea became fully ice covered particle fluxes were still relatively high (Fig. 8). The river suspension which had been transported to the region during the discharge peaks earlier in the year, evidently, settled during this season. A study in the Laptev Sea showed that the fluvial material remained in suspension during the season of maximum river discharge, probably due to high current speeds and turbulence, and settled later in the year at reduced energy levels (Wegner et al., 2003).

From October 2000 through January 2001 and in November/December 2002 organic matter contents and $\delta^{15} \mathrm{~N}$ values increased and high $\mathrm{F} 1$ scores and Asp $/ \beta$-Ala ratios indicate that organic matter was fresh (Figs. 3 and 8). During this season in 2000 (Yen 02) a large number of zooplankters and their larvae entered the cups (Nöthig, unpublished). They provided the fresh tissue enriched in ${ }^{15} \mathrm{~N}$ (Montoya et al., 2002). Although zooplankters were picked

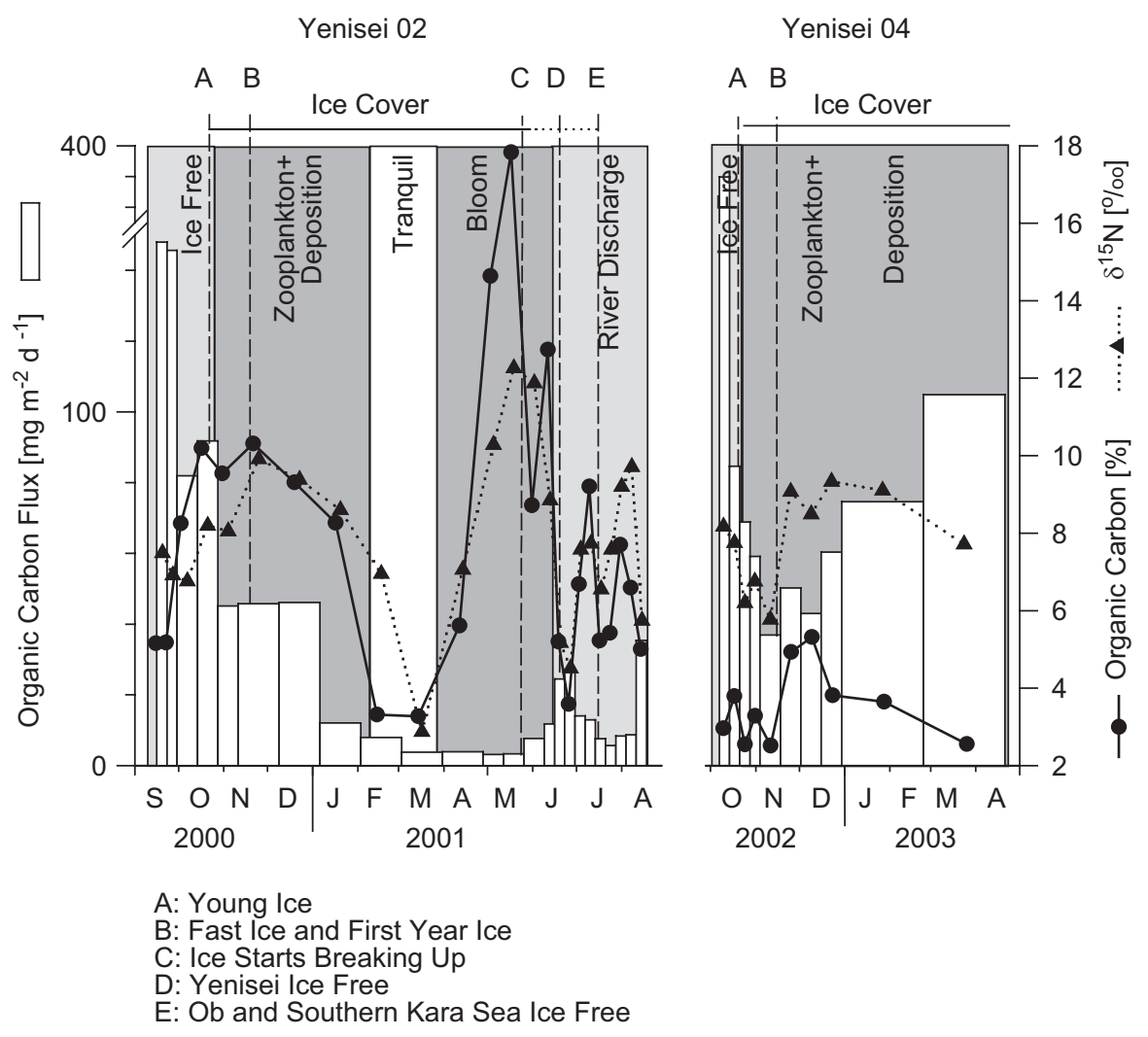

Fig. 8. Organic carbon fluxes, organic carbon percentages and $\delta^{15} \mathrm{~N}$ values in Yen 02 trap samples. Indicated are different phases of sedimentation as well as ice conditions as described in the text. 
from the cups, their partial disintegration, evidently, left an imprint on the trap samples. This was also indicated by the high fluxes of 20:1 and 22:1 fatty acid isomers (Table 1) which are synthesized mainly by copepods (Falk-Petersen et al., 1987). In a study from the Fram Strait (Werner, 2006) found that many copepods reproduced under the ice in winter and may have fed on POC which is abundant during this season. The $\delta^{13} \mathrm{C}$ minimum in November/ December 2000 (Fig. 3c) either indicated an event of lateral supply and redeposition of terrestrial material from the inner estuary or resulted from a zooplankton species strongly depleted in ${ }^{13} \mathrm{C}$ (Smith et al., 2002). Sterols support the terrestrial source: they had high fluxes as well as their maximum contents (not shown) in these two cups (Table 1). Whereas campesterol and $\beta$-sitosterol are derived from higher land plants (Huang and Meinschein, 1976; Volkmann, 1984), dinosterol and brassicasterol can be derived from both fresh water and marine algae (Fahl and Stein, 1999; Robinson et al., 1984; Thiel, 1993; Yunker et al., 1995). As fluxes and contents of all sterols were significantly correlated we can assume that the algal sterols were mainly fresh-water derived. This terrestrial signal was, however, not reflected in $\delta^{15} \mathrm{~N}$ values, possibly due to the lower nitrogen content of sediments.

During the ice covered season in 2003 (Yen 04) the proportion of lithogenic matter as well as $\delta^{13} \mathrm{C}$ values were higher than during the Yen 02 deployment. This more marine signal could be explained by a higher proportion of resuspended material from further off shore in 2003 while material settling in 2001 was derived from more in shore source areas.

In February to April 2001 (Yen 02) the fluxes were very low and all variables attained their minima (Figs. 3a-c and 8). The low $\delta^{15} \mathrm{~N}$ values indicate riverine origin of organic matter. The small amounts of material caught in the trap during this period were thus; either slow settling degraded river suspension or reworked riverine sediment. Such a tranquil period was not observed during the Yen 04 deployment indicating that sedimentation in the Kara Sea is highly dynamic and subjected to interannual variations not only during ice-free conditions but also under ice cover. Some of the differences between the two deployments may, moreover, be due to the slight shift of the position.

4.3.2.3. Ice break up and fluvial supply. In April/ May 2001 just prior to and during the first break up of the ice cover and polynya formation trap material had peak organic carbon and nitrogen contents and organic matter was freshest of all Yen trap samples (Fig. 3a-c). The latter was discerned from maxima of F1 scores, RI, Asp/B-Ala ratios as well as highest contributions of AA carbon to total organic carbon (Table 1; Fig. 3c). These signals were due to an iceassociated bloom that was dominated by diatoms (Nöthig, 2006, personal communication). Although fluxes remained low during this period (Fig. 8) the early bloom may have been very important to sustain the life cycles of other organisms such as protozoa, zooplankton or fish. It produced a marine, i.e. an enriched $\delta^{13} \mathrm{C}$ signal and was, moreover, characterised by the maximum of $\delta^{15} \mathrm{~N}$ values. This may have been due to the regime in which ice-associated blooms occurred: due to low light availability the diatoms could only survive just below the ice or in the polynyas opening up in the southern Kara Sea. The ice melting produced fresh water lenses leading to stratification of surface waters so that nitrogen became limiting and was completely taken up which is evident from $\delta^{15} \mathrm{~N}$ values up to $>12 \%$.

In June/July the Kara Sea was still ice covered except for the polynya area. The river plumes broke up the ice in the rivers and estuaries within less than one week in mid-June 2001 for the Yenisei and in mid-July for the Ob. The whole Kara Sea was ice free only in the beginning of August (http://www.seaice.de). The arrival of the river plumes as well as the timing of ice break up in the Kara Sea reveal slight interannual variations. Although fluxes of this phase were low, composition of material clearly reflected the fluvial input in their depleted $\delta^{15} \mathrm{~N}$ and $\delta^{13} \mathrm{C}$ signals as well as low organic carbon and nitrogen contents and intermediate organic matter quality (Fig. $3 \mathrm{~b}$ and c). $\delta^{15} \mathrm{~N}$ dropped to values close to the river end members (sea above) and $\delta^{13} \mathrm{C}$ values dropped from more than $-26.5 \%$ to the purely riverine value of $-28.5 \%$. The relatively low fluxes found during this season were possibly due to high current speeds in surface waters as well as strong stratification which held much of the particulate matter in suspension until autumn or even winter, similar to processes found in the Laptev Sea (Wegner et al., 2003).

\subsubsection{Seasonality of fluxes at Kara 01}

Enhanced primary productivity during the very short ice-free period in summer was reflected in high 
fluxes and/or high contents of organic matter in September/October 2001 and July/August 2002 (Fig. 4). Organic matter contents were higher and organic matter was fresher (higher Asp $/ \beta-$ Ala ratios) indicating the higher contribution from primary production during the ice-free period. As pointed out above (see 4.3.1.), F1 scores can indicate terrestrial vs. marine organic matter sources as well as the state of organic matter degradation at the Kara location. Unlike the Yen trap results, F1 scores are not correlated with organic contents or Asp/ $\beta$-Ala ratios but have a minimum during ice break up coinciding with high $\delta^{13} \mathrm{C}$ values. This shows the degraded marine nature of organic matter deposited during ice melt.

The flux pattern during the ice covered season resembled the pattern observed during the Yen 02 deployment one year before (Figs. 3 and 4) with high particle fluxes including land plant derived sterols from October to January and lowest fluxes in late winter/early spring (Table 3). Another similarity was the maximum of $\delta^{15} \mathrm{~N}$ in May/June that we attributed to an ice-associated bloom. The observed variations in stable isotopic ratios, organic matter contents and values of AA derived biogeochemical indicators were, however, smaller than those at the southern trap location and there were no correlations among these variables. One reason for this could be the, generally, more uniformly marine character of deposited organic matter at the Kara compared to the Yen location. This is also indicated by higher $\delta^{13} \mathrm{C}$ values, the stronger degradation of organic matter as well as the different sterol spectra. In contrast to the Yen 02 results not all sterol fluxes are correlated in the Kara samples. The algal derived brassicasterol had high fluxes after ice break up in 2002 whereas the land plant derived campesterol and $\beta$-sitosterol did not increase significantly (Table 3 ). We can, therefore, assume that the high brassicasterol flux was of marine origin (Yunker et al., 1995) and that the flux peak at the Kara 01 location occurring after ice break had only a weak land derived component.

\subsection{Comparison of trap results with primary productivity and sediment accumulation rates}

To study the fate of terrestrial and marine organic carbon in the Kara Sea we calculated the proportion of terrestrial organic matter in selected samples by a two-end member-mixing model

$$
\begin{aligned}
& \text { Terrestrial Organic Matter \% } \\
& \quad=\left[\frac{\delta^{13} \text { Cmarine }-\delta^{13} \text { Corganic }}{\delta^{13} \text { Cmarine }-\delta^{13} \text { Cterrestrial }}\right] 100,
\end{aligned}
$$

where $\delta^{13}$ Cmarine is the marine end member of $-22 \%$, $\delta^{13}$ Corganic is the $\delta^{13} \mathrm{C}$ value of a surface sediment or of the average of trap samples, and $\delta^{13}$ Cterrestrial is the terrestrial end member of $-28 \%$ (see 4.2.1.).

Based on these results we calculated the accumulation rates of marine and terrestrial organic carbon in surface sediment samples and in sediment traps as annual averages (Table 2). Samples were selected in a profile from the Yenisei estuary to the Kara Sea trap location (Figs. 1 and 9). The proportion of terrestrial organic carbon in traps and surface sediments is reduced from more than $80 \%$ at the southernmost station to $40 \%$ at the northernmost station close to the Kara Sea trap; the accumulation rate of terrestrial organic carbon drops from 10.7 to $0.3 \mathrm{~g} \mathrm{C} \mathrm{m}^{-2} \mathrm{a}^{-1}$ (Fig. 9).

A comparison of accumulation rates of marine organic carbon in traps and sediments with primary production is difficult as data are neither available for the period of study nor in spatial resolution. We can only use an estimate of about $22 \mathrm{~g} \mathrm{C} \mathrm{m}^{-2} \mathrm{a}^{-1}$ of Vinogradov et al. (2000) which is an average for the whole Kara Sea. Our comparison to this estimate shows that $9-28 \%$ of primary production was caught in the traps (Fig. 9). The large difference between the Yen 02 and 04 traps could indicate interannual or spatial variations of primary production as well as of resuspension, redeposition, and source of this material (see 4.3.). The preservation of marine organic carbon in surface sediments is reduced from $10 \%$ of primary productivity in the southern Kara Sea to $2 \%$ in the central Kara Sea. Northward decreasing organic matter quality is also indicated by lower organic carbon and nitrogen percentages as well as lower DI and RI values (Table 2). The stronger degradation in the central Kara Sea may be due to the lower total sediment accumulation rates (Table 2).

Composition of material caught in sediment traps and accumulated in surface sediments is similar except for organic carbon (Table 2). Degradation results in a reduction of organic carbon percentages from 3 to $7 \%$ in traps to $0.7-2 \%$ in sediments and a relative enhancement of lithogenic matter from 80 to $85 \%$ in traps to $86-88 \%$ in sediments. Biogenic opal contents are roughly around $10 \%$ in traps and sediments revealing that opal dissolution is not 


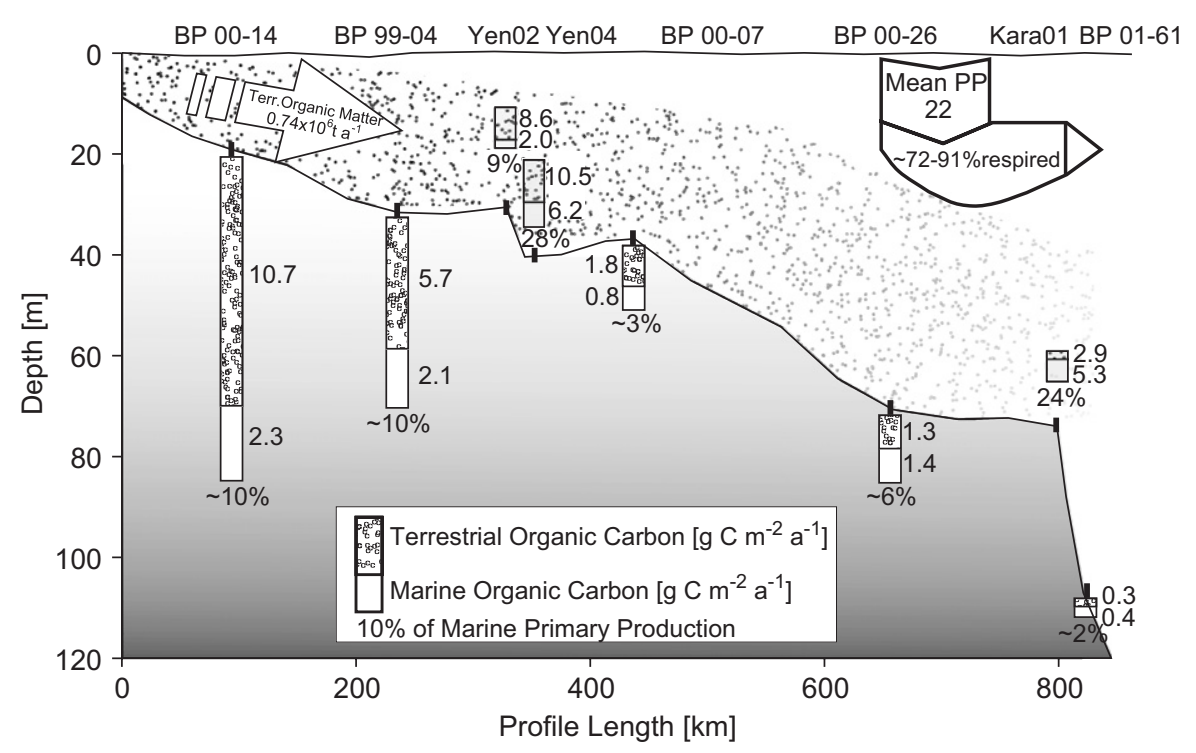

Fig. 9. Accumulation rates of marine and terrestrial organic matter in Kara Sea traps (Yen 02, Yen 04, Kara 01) and sediments (BP 00-14; BP 99-04; BP 00-07; BP 00-26; BP 01-61). All numbers are in $\mathrm{g} \mathrm{C} \mathrm{m}^{-2} \mathrm{a}^{-1}$ when not indicated differently; all percentages indicate marine organic matter as proportions of mean primary productivity. Number for mean PP is from Vinogradov et al. (2000); the amount of terrestrial organic matter is taken from Gebhardt et al. (2004); respiration in the water column has been estimated from marine organic matter accumulation in traps. Note that the bar scales are different for traps and sediments.

significant. Considering the biases of sediment trapping in a shelf environment (see 2.2.) as well as the different time scales covered by traps $(<1 \mathrm{a})$ and surface sediments $(2 \mathrm{ka})$ it is remarkable that not only the composition but also the accumulation rates are roughly similar in traps and sediments.

\section{Conclusions}

1. In analogy to surface sediment data, particulate matter fluxes in sediment traps have a decreasing fluvial imprint from the southern to the central Kara Sea.

2. The season of ice break up in May/June is characterised by an early bloom of ice-associated algae in the polynya area of the southern Kara Sea. This bloom does not produce increased fluxes but fresh organic matter that may be important to sustain the life cycles of organisms after a period of light limitation. In the central Kara Sea settling particles caught during ice break up are of degraded marine nature and are dominated by material released during ice melt.

3. The season of main river discharge in June to August is characterised by low material fluxes in the southern Kara Sea that are of terrestrial origin.
4. Peak fluxes occur during the ice-free season in September/October and organic matter is of mixed terrestrial and planktonic origin.

5. High fluxes occur during the ice covered season in all traps and show that the riverine material supplied earlier can settle only as current speeds in surface waters decrease. Microscopic and biogeochemical evidence show that zooplankton reproduce in early winter. Moreover, resuspension, lateral transport and resedimentation determine sedimentation processes during the ice covered season.

6. Despite the possible methodological biases of sediment traps in shallow water and the different time scales of sediment trapping and surface sediment accumulation, total annual fluxes in traps are in the same order of magnitude as accumulation rates in surface sediments and have a similar composition.

7. Terrestrial organic carbon accumulation rates in sediments decrease by a factor of 30 from the southern to the central Kara Sea while the contribution of terrestrial to total organic carbon in traps and sediments decreases from $>80 \%$ to $40 \%$.

8. Marine organic carbon preservation in surface sediments is reduced from $10 \%$ of primary 
production in the estuaries to $2 \%$ in the central Kara Sea which is probably related to decreasing rates of sedimentation.

\section{Acknowledgments}

We thank the officers and crew of the RV "Akademik Boris Petrov" for their excellent work at sea. We are greatly indebted to the colleagues of the Russian-German Research Program "SIRRO" for cooperation on board as well as the fruitful discussions during the meetings. Financial support by the German Ministry of Education, Science, Research and Technology (BMBF) (Grants nos. 03G0539C and 03G0547C) and the Russian Foundation of Basic Research is gratefully acknowledged. Special thanks go to Ingo Harms for discussions and supplying the insolation data as well as to two anonymous reviewers who have greatly helped to improve the manuscript.

\section{References}

Aagaard, K., 1994. Contamination of the arctic. Ocean processes. Arctic Research of the United States 8, 21-33.

Altabet, M., 1996. Nitrogen and carbon isotopic tracers of the source and transformation of particles in the deep sea. In: Ittekkot, V., Schäfer, P., Honjo, S., Depetris, P.J. (Eds.), Particle Flux in the Ocean, Vol. 57. Wiley, Chichester SCOPE, pp. 155-184.

Altabet, M.A., Pilskaln, C.H., Thunell, R.C., Pride, C., Sigman, D., Chavez, F., Francois, R., 1999. The nitrogen isotope biogeochemistry of sinking particles from the margin of the Western North Pacific. Deep-Sea Research I 46, 655-679.

Antia, A.N., 2005. Solubilization of particles in sediment traps: revising the stoichiometry of mixed layer export. Biogeosciences 2, 189-204.

Bobrovitskaya, N.N., Zubkova, K.M., Meade, R.H., 1996. Discharges and yields of suspended sediment in the Ob' and Yenisei rivers of Siberia. In: Walling, D.E., Webb, B.W. (Eds.), Erosion and Sediment Yield: global and regional perspectives, vol. 236. IHAS, pp. 115-123.

Bobrovitskaya, N.N., Skakalsky, B.G., Zubkova, K.M., Dobrotvorskaya, G.I., Petrova, I.V., Tsivjyan, M.V., Chistyakova, N.I. and Yanuta, V.G., 1997. Hydrologic and hydrochemical data for the Ob-Irtysh and Yenisey river systems of Central Russia, 1954-1988. Open File Report, United States Geological Survey, pp. 97-232.

Christie, W.W., 1990. Methylation of fatty acids. Lipid Technology 2 (48-49), 79-80.

Conte, M.H., Eglinton, G., Madureira, L.A.S., 1992. Long-chain alkenones and alkyl alkenoates as palaeotemperature indicators: their production, flux and early sedimentary diagenesis in the Eastern North Atlantic. Organic Geochemistry 19 (1-3), 287-298.

Dauwe, B., Middelburg, J.J., 1998. Amino acids and hexosamines as indicators of organic matter degradation state in
North Sea sediments. Limnology and Oceanography 43, 782-798.

Dauwe, B., Middelburg, J.J., Hermann, P.M.J., Heip, C.H.R., 1999. Linking diagenetic alteration of amino acids and bulk organic matter reactivity. Limnology and Oceanography 44, 1809-1814.

Deubel, H., Engel, M.H., Fetzer, I., Gagaev, S., Hirche, H.-J., Larionov, V.V., Lubin, P., Lubina, O., Nöthig, E.-M., Okolodkov, Y., Rachor, E., 2003. The southern Kara Sea ecosystem: phytoplankton, zooplankton and benthos communities influenced by river-run-off. In: Stein, R., Fahl, K., Fütterer, D.K., Galimov, E., Stepanets, O. (Eds.), Siberian River Run-off in the Kara Sea: Characterisation, Quantification, Variability, and Environmental Significance. Proceedings in Marine Science. Elsevier, Amsterdam, pp. 237-265.

Dittmers, K., Niessen, F., Stein, R., 2003. Holocene sediment budget and sedimentary history for the $\mathrm{Ob}$ and Yenisei estuaries. In: Stein, R., Fahl, K., Fütterer, D.K., Galimov, E., Stepanets, O. (Eds.), Siberian River Run-off in the Kara Sea: Characterisation, Quantification, Variability, and Environmental Significance. Proceedings in Marine Science. Elsevier, Amsterdam, pp. 457-488.

Dmitrenko, I.A., Gribanov, V.A., Volkov, D.L. and Kassens, H., 1999. Impact of river discharge on the sea land fast ice extention in the Russian arctic shelf area. In: Tuhkuri, J., Riska, K., (Eds.), In: Proceedings of the 15th International Conference on Port and Ocean Enginering under Arctic Conditions. Espoo, Finland, 23-27 August, pp. 311-321.

Fahl, K., Stein, R., 1999. Biomarkers as organic-carbon-source and environmental indicators in the late quaternary Arctic Ocean: problems and perspectives. Marine Chemistry 63 (3-4), 293-309.

Fahl, K., Stein, R., Gaye-Haake, B., Gebhardt, A.C., Kodina, L.A., Unger, D., Ittekkot, V., 2003. Biomarkers in surface sediments from the $\mathrm{Ob}$ and Yenisei estuaries and the southern Kara Sea: evidence for particulate organic carbon sources, pathways and degradation. In: Stein, R., Fahl, K., Fütterer, D.K., Galimov, E., Stepanets, O. (Eds.), Siberian River Runoff in the Kara Sea: Characterisation, Quantification, Variability, and Environmental Significance. Proceedings in Marine Science. Elsevier, Amsterdam, pp. 329-348.

Falk-Petersen, S., Sargent, J.R., Tande, K., 1987. Lipid composition of zooplankton in relation to the sub-Arctic food web. Polar Biology 8, 115-120.

Fernandes, M.B., Sicre, M.-A., 1999. The importance of terrestrial organic carbon inputs on Kara Sea shelves as revealed by $n$-alkanes, $\mathrm{OC}$ and $\delta^{13} \mathrm{C}$. Organic Geochemistry 31, 363-374.

Gardner, W.D., 1999. Sediment trap technology and sampling in surface waters. In: Hanson, R.B., Ducklow, H.W., Field, J.G. (Eds.), The Dynamic Ocean Carbon Cycle: A Midterm Synthesis of the Joint Global Ocean Flux Study. Cambridge University Press, pp. 240-281.

Gaye-Haake, B., Unger, D., Nöthig, E.-M., Okolodkov, Y., Fahl, K., Ittekkot, V., 2003. Particle fluxes from short-term sediment trap deployments in late summer in the southern Kara Sea. In: Stein, R., Fahl, K., Fütterer, D.K., Galimov, E., Stepanets, O. (Eds.), Siberian River Run-off in the Kara Sea: Characterisation, Quantification, Variability, and Environmental Significance. Proceedings in Marine Science. Elsevier, Amsterdam, pp. 309-328. 
Gaye-Haake, B., Lahajnar, N., Emeis, K.-C., Unger, D., Rixen, T., Suthhof, A., Ramaswamy, V., Schulz, H., Paropkari, A.L., Guptha, M.V.S., Ittekkot, V., 2005. Stable nitrogen isotopic ratios of sinking particles and sediments from the northern Indian Ocean. Marine Chemistry 96, 243-255.

Gebhardt, A.C., Gaye-Haake, B., Unger, D., Lahajnar, N., Ittekkot, V., 2004. Recent particulate organic carbon and total suspended matter fluxes from the $\mathrm{Ob}$ and Yenisei Rivers into the Kara Sea (Siberia). Marine Geology 207, 225-245.

Goni, M.A., Yunker, M.B., Macdonald, R.W., Eglinton, T.I., 2005. The supply and preservation of ancient and modern components of organic carbon in the Canadian Beaufort Shelf of the Arctic Ocean. Marine Chemistry 93, 53-73.

Gowen, R.J., Stewart, B.M., Mills, D.K., Elliott, P., 1995. Regional differences in stratification and its effect on phytoplankton production and biomass in the northwestern Irish Sea. Journal of Plankton Research 17 (4), 753-769.

Guo, L., Semiletov, I., Gustafsson, Ö., Ingri, J., Andersson, P., Dudarev, O., White, D., 2004a. Characterization of Siberian Arctic coastal sediments: implications for terrestrial organic carbon export. Global Biogeochemical Cycles 18 (GB1036), doi:10.1029/2003GB002087.

Guo, L., Tanaka, T., Wang, D., Tanaka, N., Akihiko, M., 2004b. Distribution, speciation and stable isotope composition of organic matter in the southeastern Bering Sea. Marine Chemistry 91, 211-226.

Gust, G., Kozerski, H.-P., 2000. In situ sinking-particle flux from collection rates of cylindrical traps. Marine Ecology Progress Series 208, 93-106.

Gust, G., Byrne, R.H., Bernsteil, R.E., Betzer, P.R., Bowles, W., 1992. Particle fluxes and moving fluids: experience from synchronous trap collections in the Sargasso Sea. Deep-Sea Research I 39, 1071-1083.

Gust, G., Bowles, W., Giordano, S., Hüttel, M., 1996. Particle accumulation in a cylindrical sediment trap under laminar and turbulent steady flow: an experimental approach. Aquatic Science 58, 297-326.

Hargrave, B.T., Walsh, I.D., Murray, D.W., 2002. Seasonal and spatial patterns in mass and organic matter sedimentation in the North Water. Deep-Sea Research II 49, 5227-5244.

Harms, I.H., Karcher, M.J., Dethleff, D., 2000. Modeling Siberian river runoff-implications for contaminant transport in the Arctic Ocean. Journal of Marine Systems 27, 95-115.

Harms, I.H., Hübner, U., Backhaus, J.O., LKulakov, M., Stanovoy, V., Stepanets, O.V., Kodina, L.A., Schlitzer, R., 2003. Salt intrusion in Siberian river estuaries: observations and model experiments in $\mathrm{Ob}$ and Yenisei. In: Stein, R., Fahl, K., Fütterer, D.K., Galimov, E., Stepanets, O. (Eds.), Siberian River Run-off in the Kara Sea: Characterisation, Quantification, Variability, and Environmental Significance. Proceedings in Marine Science. Elsevier, Amsterdam, pp. 27-46.

Hecky, R.E., Mopper, K., Kilham, P., Degens, E.T., 1973. The amino acid composition of diatom cell-walls. Marine Biology 19, 1999-2033.

Hirche, H.J., Kosobokova, K.N., Gaye-Haake, B., Harms, I., Meon, B., Nöthig, E.-M., 2006. Structure and function of comtemporary food webs on Arctic shelves: a panarctic comparison. The pelagic system of the Kara Sea-communities and components of carbon flow. Progress in Oceanography 71, 288-313.

Holmes, R.M., Peterson, B.J., Zhulidov, A.V., Gordeev, V., Makkaveev, P.A., Stunzhas, P.A., Kosmenko, L.S., Köhler,
H., Shiklomanov, A.I., 2001. Nutrient chemistry of the $\mathrm{Ob}$ and Yenisei rivers, Siberia: results from June 2000 expedition and evaluation of long-term data sets. Marine Chemistry 75, 219-227.

Holmes, R.M., McClelland, J.W., Peterson, B.J., Shiklomanov, I.A., Shiklomanov, A.I., Zhulidov, A.V., Gordeev, V., Bobrovitskaya, N.N., 2002. A circumpolar perspective on fluvial sediment flux to the Arctic Ocean. Global Biogeochemical Cycles 16 (4), doi:10.1029/2001GB001849.

Honjo, S., Francois, R., Manganini, S., Dymond, J., Collier, J.R., Robert, W., 2000. Particle fluxes to the interior of the Southern Ocean in the Western Pacific sector along $170^{\circ} \mathrm{W}$. Deep-Sea Research II 47 (15-16), 3521-3548.

Huang, W.Y., Meinschein, W.G., 1976. Sterols as source indicators of orgnaic materials in sediments. Geochimica et Cosmochimica Acta 40, 323-330.

Ingalls, A.E., Lee, C., Wakeham, S.G., Hedges, J.I., 2003. The role of biominerals in the sinking flux and preservation of amino acids in the Southern Ocean along $170^{\circ} \mathrm{W}$. Deep-Sea Research II 50, 713-738.

Ingalls, A.E., Liu, Z., Lee, C., 2006. Seasonal trends in the pigment and amino acid compositions of sinking particles in biogenic $\mathrm{CaCO}_{3}$ and $\mathrm{SiO}_{2}$ dominated regions of the Pacific sector of the Southern Ocean along $170^{\circ} \mathrm{W}$. Deep-Sea Research I 53, 836-859.

Ittekkot, V., Deuser, W.G., Degens, E.T., 1984. Seasonlity in the fluxes of sugars, amino acids, and amino sugars to the deep ocean: Sargasso Sea. Deep-Sea Research 31, 1057-1069.

Jennerjahn, T., Ittekkot, V., 1999. Changes in organic matter from surface waters to continental slope sediments off the Sao Francisco River, eastern Brazil. Marine Geology 161, 129-140.

Kähler, P., Bauerfeind, E., 2001. Organic particles in a shallow sediment trap: substantial loss to the dissolved phase. Limnology and Oceanography 46 (3), 719-723.

Krishnamurthy, R.V., Machavaram, M., Baskaran, M., Brooks, J.M., Champs, M.A., 2001. Organic carbon flow in the Ob, Yenisei rivers and Kara Sea of the Arctic Region. Marine Pollution Bulletin 42, 726-732.

Lee, C., 1988. Amino acids and amine biogeochemistry in marine particulate matter material and sediments. In: Blackburn, T.H., Sörensen, J. (Eds.), Nitrogen Cycling in Coastal Marine Environments. SCOPE, Wiley, London, pp. 125-141.

Lee, C., Cronin, C., 1982. The vertical flux of particulate organic nitrogen in the sea: decomposition of amino acids in the Peru upwelling area and the equatorial Atlantic. Journal of Marine Research 40, 227-251.

Lee, C., Cronin, C., 1984. Particulate amino acids in the sea: effects of primary productivity and biological decomposition. Journal of Marine Research 42, 1075-1097.

Lee, C., Wakeham, S.G., Hedges, J.I., 1988. The measurment of oceanic particle flux-are 'swimmers' a problem? Oceanography 1 (2), 34-36.

Lee, C., Wakeham, S.G., Hedges, J.I., 2000. Composition and flux of particulate amino acids and chloropigments in equatorial Pacific seawater and sediments. Deep-Sea Research I 47, 1535-1568.

Lisitzyn, A.P., 1995. The marginal filter of the ocean. Oceanology (English Translation) 34 (5), 671-682.

Lourey, M.J., Trull, T.W., Sigman, D.M., 2003. Sensitivity of $\delta^{15} \mathrm{~N}$ of nitrate, surface suspended and deep sinking particulate nitrogen to seasonal nitrate depletion in the 
Southern Ocean. Global Biogeochemical Cycles 17 (3), doi:10.1029/2002GB001973.

McCallister, S.L., Bauer, J.E., Cherrier, J.E., Ducklow, H.W., 2004. Assessing sources and ages of organic matter supporting river and estuarine bacterial production: a multiple-isotope $\left(\Delta^{14} \mathrm{C}, \delta^{13} \mathrm{C}\right.$, and $\left.\delta^{15} \mathrm{~N}\right)$ approach. Limnology and Oceanography 49 (5), 1687-1702.

Meade, R.H., Bobrovitskaya, N.N., Babkin, V.I., 2000. Suspended-sediment and fresh-water discharges in the $\mathrm{Ob}$ and Yenisey rivers, 1960-1988. International Journal of Earth Sciences 89, 461-469.

Milliman, J.D., Meade, R.H., 1983. World-wide delivery of river sediment to the oceans. The Journal of Geology 91 (1), 1-21.

Montoya, J.P., Horrigan, S.G., McCarthy, J.J., 1991. Rapid, storm-induced changes in natural abundance of ${ }^{15} \mathrm{~N}$ in planktonic ecosystems, Chesapeake Bay, USA. Geochimica et Cosmochimca Acta 55, 3627-3638.

Montoya, J.P., Carpenter, E.J., Capone, D.G., 2002. Nitrogen fixation and nitrogen isotope abundance in zooplankton of the oligotrophic North Atlantic. Limnology and Oceanography 47 (6), 1617-1628.

Mortlock, R.A., Froelich, P.N., 1989. A simple method for the rapid determination of biogenic opal in pelagic marine sediments. Deep-Sea Research 36, 1415-1426.

Nagel, B., Gaye, B. Kodina, L.,. Stable carbon and nitrogen isotopes as indicators of organic matter sources in the Kara Sea. Submitted.

Nöthig, E.-M., 2005. Personal communication.

Nöthig, E.-M., Okolodkov, Y., Larionov, V.V., Makarervich, R.R., 2003. Phytoplankton distribution in the inner Kara Sea: a comparison of three summer investigations. In: Stein, R., Fahl, K., Fütterer, D.K., Galimov, E., Stepanets, O. (Eds.), Siberian River Run-off in the Kara Sea: Characterisation, Quantification, Variability, and Environmental Significance. Proceedings in Marine Science. Elsevier, Amsterdam, pp. 163-183.

Pavlov, V.K., Pfirman, S.L., 1995. Hydrographic structure and variability of the Kara Sea: implications for pollutant distribution. Deep-Sea Research II 42 (6), 1369-1390.

Peterson, B.J., Holmes, R.M., McClelland, J.W., Vörösmarty, C.J., Lammers, R.B., Shiklomanov, A.I., Shiklomanov, I.A., Rahmstorf, S., 2002. Increasing rivers discharge to the Arctic Ocean. Science 298, 2171-2173.

Pivovarov, S.V., Schlitzer, R., Novikhin, A., 2003. River run-off influence on the water mass formation in the Kara Sea. In: Stein, R., Fahl, K., Fütterer, D.K., Galimov, E., Stepanets, O. (Eds.), Siberian River Run-off in the Kara Sea: Characterisation, Quantification, Variability, and Environmental Significance. Proceedings in Marine Science. Elsevier, Amsterdam, pp. 9-25.

Ramseier, R.O., Bauerfeind, E., Garrity, C., Walsh, I.D., 1997. Seasonal variability of sediment trap collection in the Northeast Water polynya. Part 1: sea-ice parameters and particle flux. Journal of Marine Systems 10, 359-369.

Robinson, N., Eglinton, G., Brassell, S.C., Cranwell, P.A., 1984. Dinoflagellate origin for sedimentary $4 \alpha$-methylsteroids and $5 \alpha(\mathrm{H})$-stanols. Nature 308, 439-442.

Sackett, W.M., Eadie, B.J. and Exner, M.E., 1974. Stable isotope composition of organic carbon in recent Antarctic sediments. Advance Organic Geochemistry. In: Proceedings of the International Meeting, Sixth (1974), Meeting Date 1973; In: Tissot, B.; Bienner, F.(Eds.), pp. 661-671.
Schubert, C.J., Calvert, S.E., 2001. Nitrogen and carbon isotopic composition of marine and terrestrial organic matter in Arctic Ocean sediments: implications for nutrient utilization and organic matter composition. Deep-Sea Research I 48, 789-810.

Shmelkov, B., Latko, A., Stanovoy, V., 2002. Hydrological conditions in the Kara Sea during summer cruise 2001. Berichte zur Polar- und Meeresforschung 419, 6-12.

Sigman, D.M., Altabet, M.A., McCorkle, D.C., Francois, R., Fischer, G., 2000. The $\delta^{15} \mathrm{~N}$ of nitrate in the Southern Ocean: nitrogen cycling and circulation in the ocean interior. Journal of Geophysical Research 105 (C8), 19,599-19,614.

Smith, S.L., Henrichs, S.M., Rho, T., 2002. Stable C and N isotopic composition of particles and zooplankton over the southeastern Bering Sea shelf. Deep-Sea Research II 49, 6031-6050.

Stein, R., Fahl, K., Fütterer, D.K., Galimov, E.M., Stepanets, O.V.E., 2003. Siberian River run-off in the Kara Sea: characterisation, quantification, variability, and environmental significance. Proceedings in Marine Sciences 6, 484.

Stolbovoi, V., McCallum, I., 2002. Land resources of Russia. CD-ROM, International Institute of Applied System Analysis, Laxenburg, Austria and the Russian Academy of Sciences, Moscow. Available on the internet: 〈http:// www.iiasa.ac.at/Research/FOR/russia_cd/index.htm $\rangle$.

Syvitski, J.P.M., 2002. Sediment discharge variability in Arctic rivers: implications for a warmer future. Polar Research 21 (2), 323-330

Telang, S.A., Pocklington, R., Naidu, A.S., Romankevich, E.A., Gitelson, I.I. and Gladyshev, M.I., 1991. Carbon and mineral trnsport in major North American, Russian Arctic, and Siberian rivers: the St. Lawrence, the Mackenzie, the Yukon, the Arctic Alaskan, the Arctic Basin rivers in the Soviet Union and the Yenisei. In: Degens, E.T., Kempe, S., Richey, J. (Eds.), Biogeochemistry of Major World Rivers. SCOPE, vol. 42, pp. 75-104.

Thiel, V., 1993. Untersuchungen von Biomarkern als Faziesindikatoren für limnische Ablagerungsräume. Hamburg University Germany, Masters Thesis, pp. 137.

Unger, D., Gaye-Haake, B., Gebhardt, A.C., Ittekkot, V., 2005. Biogeochemistry of suspended and sedimentary material from the $\mathrm{Ob}$ and Yenisei rivers and the adjacent Kara Sea: amino acids and amino sugars. Continental Shelf Research 25, 437-460.

Vedernikov, V.I., Demidov, A.B., Sud'bin, A.I., 1995. Primary production and chlorophyll in the Kara Sea in September 1993. Oceanology (English Translation) 34 (5), 630-639.

Vinogradov, M.E., Vedernikov, V.I., Romankevich, E.A., Vetrov, A.A., 2000. Components of the carbon cycle in the Russian Arctic seas: primary production and flux of $\mathrm{C}_{\text {org }}$ from the photic layer. Oceanology (English Translation) 40 (2), 204-215.

Volkmann, J.K., 1984. A review of sterol markers for marine and terrigenous organic matter. Organic Geochemistry 9, 83-99.

Wassmann, P., Bauernfeind, E., Fortier, M., Fukuchi, M., Hargrave, B., Moran, B., Noji, T., Nöthig, E.-M., Olli, K., Sasaki, H., Shevchenko, V., 2004. Particulate organic carbon flux to the Arctic Ocean sea floor. In: Stein, R., MacDonald, R.W. (Eds.), The Organic Carbon Cycle in the Arctic Ocean. Springer, Berlin, Heidelberg, pp. 101-138.

Wegner, C., Hölemann, J.A., Dmitrenko, I., Kririlov, S., Tuschling, K., Abramova, E., Kassens, H., 2003. Suspended particulate 
matter on the Laptev Sea shelf (Siberian Arctic) during ice free conditions. Estuarine, Coastal and Shelf Science 57, 55-64.

Werner, I., 2006. Seasonal dynamics of sub-ice fauna below pack ice in the Arctic (Fram Strait). Deep-Sea Research I 53, 294-309.
Yunker, M.B., Macdonald, R.W., Veltkamp, D.J., Cretney, W.J., 1995. Terrestrial and marine biomarkers in a seasonlly ice covered Arctic estuary-integration of multivariate and biomarker approaches. Marine Chemistry 49, 1-50. 